\title{
Confirming Municipal Liberties
}

If we wish to understand the important role that ceremonial entries played in the confirmation of urban liberties, we must begin our analysis with an examination of the extramural greeting, as this was the first point of direct contact between the monarch and the urban elite on the day of the entry. While historians typically approach the formal welcome from the king's perspective, this chapter examines its value for civic elites. From the very beginning of an entry, municipal administrations across France used the extramural encounter to assert the extent of their power both to those people who travelled with the king and to the wider urban population. By standing across the road and bringing a halt to the king's cortège at the limit of their jurisdiction, urban rulers placed themselves at the forefront of the extramural greeting. Civic councils used this meeting to highlight their privileged relationship with the monarch, from whom their power derived. ${ }^{1}$ The members of the urban delegation were dressed in identical uniforms, which alerted the king to their status and allowed him to pick out the municipal elite from the mass of townspeople who gathered to watch the event. For example, during his extramural greeting at Tournai in 1355 John II invited those people dressed in the municipal livery (i.e. the town council) to dine with him at his lodgings that evening. ${ }^{2}$ This chapter will show how municipal councils devised a range of strategies to ensure that they remained visible and at the forefront of the extramural greeting. In sum, urban governments created a ceremonial space in front of the city gate, where they could speak to the monarch directly and petition him to confirm their rights.

1 Joël Blanchard, 'Les entrées royales: pouvoir et présentation du pouvoir à la fin du Moyen Age', Littérature 50 (1983), 7.

2 La Grange, 'Entrées des souverains', 28. For municipal uniforms see: S. Mouysset, 'Rouge et noire, la robe fait le consul: l'exemple de Rodez aux XVI et XVII ${ }^{\mathrm{e}}$ siècles', in Denise Turrel, ed., Regards sur les sociétés modernes, $X V^{e}-X V I I I^{e}$ siècle. Mélanges offerts à Claude Petitfrère (Tours, 1997), 123-32; Denise Turrel, 'La "livrée de distinction": les costumes des magistrats municipaux dans les entrées royales des XVI ${ }^{\mathrm{e}}$ et XVII ${ }^{\mathrm{e}}$ siècles', in Jean-François Eck and Michel Lescure, eds., Construction, reproduction et représentation des patriciats urbains de l'antiquité au XXe siècle (1999), 469-86. 


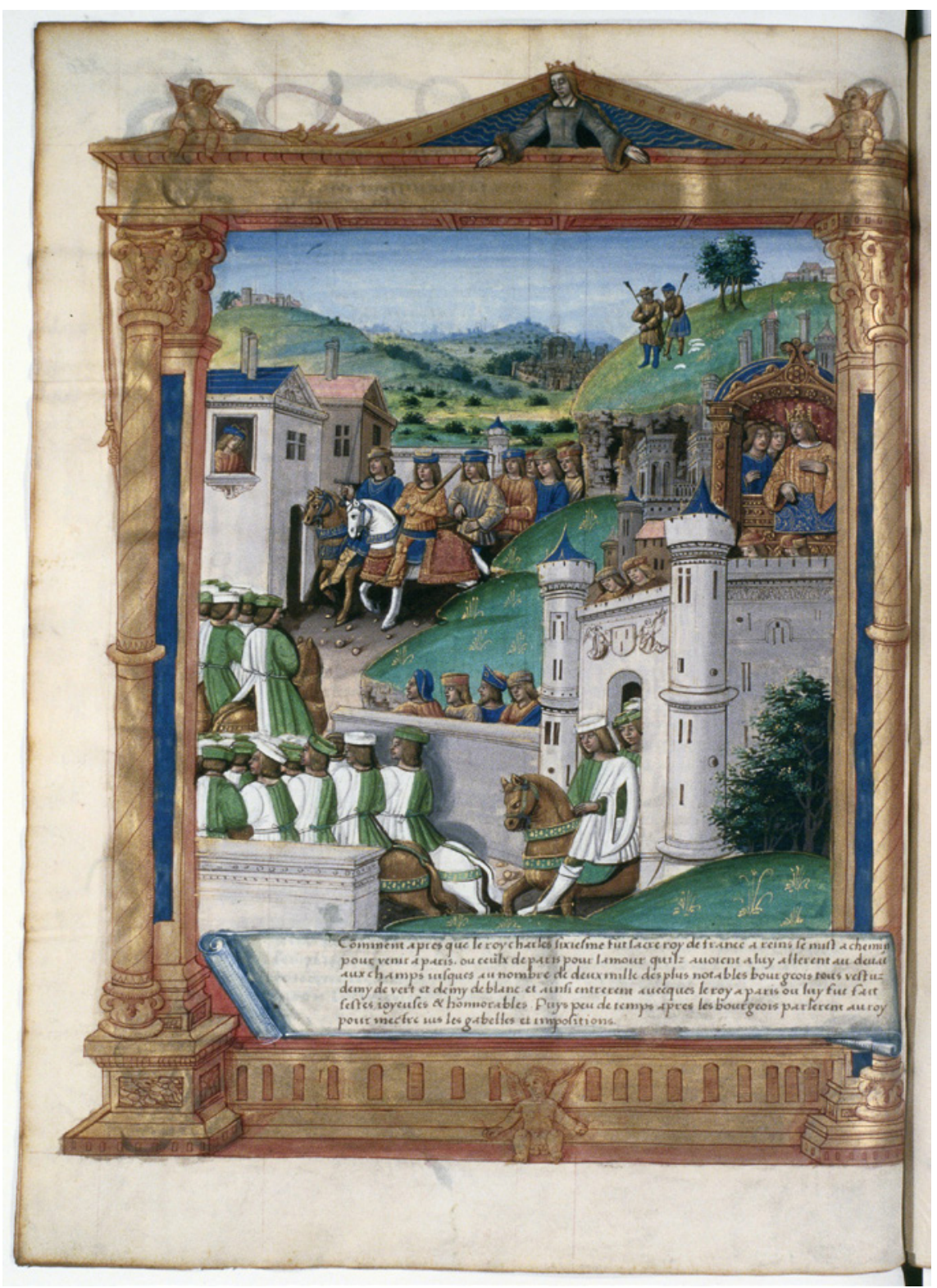

FIGURE 1 Charles VI greeted on horseback by the municipal council at his inaugural entry into Paris in 1380. Bibliothèque Nationale de France 138, FOL. 26oV. 


\section{The Harangue}

While the verbal expression of welcome (the harangue) was one of the most important elements in the extramural meeting, historians frequently pass over the content of the speech and the manner in which it was delivered in favour of examining the pageantry staged at the gate of entry. Yet, as the harangue was a pivotal moment in the town's initial encounter with the king, urban elites invested a considerable amount of time and effort into its preparation. Civic administrations hoped that a pleasing greeting would open a channel of dialogue with the monarch, which they could use to petition him for rights. From the outset of the ceremony, municipal elites sought to persuade the king that they were maintaining order on his behalf, in return for which they expected to receive his confirmation of the privileges that upheld their authority over urban political structures. Municipal administrations papered over the manifold fractures and divisions in urban society and greeted the king on behalf of the wider community. This was not the moment in the ceremony for urban elites to present the king with grievances regarding their disputes with other social groups (that would come later, when urban administrations submitted their petitions to receive new rights and powers); rather, the extramural greeting provided an opportunity for civic leaders to convince the king that they were maintaining control over urban populations on his behalf. As the person who principally embodied municipal authority, the mayor regularly delivered the greeting speech which he used to persuade the king that he spoke on behalf of the entire community. For instance, when Charles v entered Paris alongside his uncle, Emperor Charles IV, in 1378, the prévôt-des-marchands, Jean Fleury, welcomed the two monarchs on behalf of 'the bourgeois of the good town. ${ }^{3}$ Alternatively, senior members of the municipal administration who were in possession of excellent verbal skills could be asked to make the speech. When Charles viI entered Saint-Flour in 1437, the consul Pierre Gillette delivered the harangue. Gillette was known to be an expert speaker and he acted as SaintFlour's ambassador during key moments of contact with the Crown. ${ }^{4}$ The consuls expected that Gillette's expertise in dealing with the king and his officials would benefit the town during negotiations for privileges.

Urban councils regularly asked lawyers to deliver the greeting. To give one example, when Charles viII entered Abbeville on 17 June 1493 the lawyer

3 R. Delachenal, ed., Chronique des règnes de Jean II et Charles V, 4 vols (Paris, 1910-20), ii. 210; BNF Collection français 4316, fol. $6 \mathrm{v}$.

4 Marcellin Boudet, 'Charles VII à Saint-Flour et la prélude de la praguerie', Annales du Midi 6 (1894), 308. 
and échevin Jehan Caudel welcomed the king on behalf of the municipal council. ${ }^{5}$ By virtue of their profession, lawyers such as Caudel were expected to be proficient in delivering persuasive speeches. It was important that speakers delivered first-rate greetings because urban governments needed to convince the king that he should confirm their rights at this point in the ceremony. In addition, as the gens de loi were coming to replace merchants in municipal governments across France during the later fifteenth century, the placing of lawyers such as Caudel at the forefront of ceremonial entries provided these legal experts with a means to advance their social position. ${ }^{6}$ As this example highlights, rather than providing a moment for the reinforcing of a static social order, the extramural greeting was a dynamic element in the entry and it reflected the wider changes taking place in urban communities as new socioeconomic groups rose to power.

Lawyers' participation in the extramural greeting was also part of a wider trend, whereby the administrations of the kingdom's principal cities began to employ professional speakers to deliver the harangue on their behalf from the late fifteenth century. Indeed, we find a growing reluctance amongst members of civic governments to give the welcoming speech to the king. For example, none of Vienne's consuls wanted to deliver the greeting to Francis I in $1536 .^{7}$ As there was an expectation that members of urban governments would set aside personal concerns to act in the good of their town, such moments of discord threatened to undermine the credibility of a civic administration's right to rule. Some municipal governments punished people who refused to give the greeting speech because their disobedience threatened to shatter the image of civic unity they were constructing for the ruler (as well as damaging the overall quality of the harangue). Two of Dijon's civic councillors (Nicolas and Pierre Berbis) were stripped of their offices when they refused to make the greeting speech to Philip the Good in $1436 .^{8}$ As Nicolas and Pierre were not prepared to act for the wider benefit of Dijon's ruling elite, they were denied the privileges gained from holding a senior post in the city's administration. Although the position of speaker was an honourable one, the expectations

5 Ledieu, 'Charles VIII à Abbeville', 56 .

6 For the expansion of lawyers in municipal governments, see: Roger Doucet, Les institutions de la France au XVIe siècle, 2 vols (Paris, 1948), i. 363; Frederick M. Irvine, 'From renaissance city to ancien régime capital: Montpellier, c.1500-160o', in Benedict, Cities and Social Change, 125; Richard Gascon, Grand commerce et vie urbaine au XVIe siècle: Lyon et ses marchands (environs de 1520-environs de 1580), 2 vols (Paris, 1971), 412.

7 Thomas Mermet, Ancienne chronique de Vienne (Vienne, 1845), 182.

8 Gouvenain, Inventaire sommaire, Dijon, i. 33 . 
placed on the individual to make an appropriate greeting meant that it was not always popular. When six members of Amiens' town council declined the invitation to greet Henry II in August 1558, the mayor was forced to look beyond the ranks of the civic administration to find a suitable candidate. ${ }^{9}$ Although the échevin Nicole de Nybat had formally welcomed the bishop of Amiens, Nicholas de Pellevé, at his inaugural entry in 1555, he declined the mayor's request to deliver the greeting to Henry II. ${ }^{10}$ Nybat's rejection of the commission is understandable, as a royal harange was of greater political and economic importance than a speech to a bishop.

The formal extramural welcome was tightly choreographed and the speaker had to make a sequence of appropriate gestures when delivering the harangue. ${ }^{11}$ Gestures were a crucial means of communication in pre-modern societies and deliberate bodily actions (such as kneeling) lent weight to sentiments communicated in the speeches. ${ }^{12}$ Yet the pressure put on speakers to make accomplished greetings could give rise to mistakes. When Francis I returned from Italy to France in 1516 after achieving victory against the Swiss at the battle of Marignano, Marseille was the first town he entered. To celebrate Francis's success on the battlefield, the municipal council prepared a spectacular entry designed to highlight the king's military prowess. In keeping with this theme, two civic representatives dressed as the Roman gods Mars and Vulcan delivered the greeting speech. Unfortunately, the strain of the situation led the deputies to forget the words of the greeting. ${ }^{13}$ As well as embarrassing civic councils, mistakes could have important political and economic consequences because an entry's success determined the scale of the grants towns obtained from the king.

As a failed greeting speech could diminish a town's standing with the king, municipal councils began to move away from punishing recalcitrant speakers

9 They employed the royal prévot to deliver the greeting: Aм Amiens в в 31, fol. 123v.

10 AM Amiens Bв 27, fol. 85v.

11 See, for example: La Grange, 'Entrées des souverains', 44-45; AM Amiens Bв 9, fol. 115v; Ledieu, 'Charles VIII à Abbeville', 56 .

12 For the use of gesture see: Peter Burke, 'The Language of Gesture in Early Modern Italy', in Peter Burke, Varieties of Cultural History (Cambridge, 1997), 71-83; Lucie Desjardins, Le corps parlant. Savoirs et représentation des passions au XVIIe siècle (Saint-Foy and Paris, 200o), 129-39; Marcel Mauss, 'The Techniques of the Body', Economy and Society 2 (1973), 70-88; Robert Muchembled, 'The order of gestures: a social history of sensibilities under the Ancien Régime in France', in Jan Bremmer and Herman Roodenburg, eds., A Cultural History of Gesture: From Antiquity to the Present Day (Cambridge, 1991), 129-51.

13 Pierre Jourda, Marguerite d'Angoulême, duchesse d'Alençon, reine de Navarre (1492-1549): Étude biographique et littéraire (Paris, 1930), 49. 
to appoint expert orators (often drawn from beyond their ranks) to deliver the harangue on their behalf. Urban administrations attached so great an importance to the harangue's power to persuade the king both to confirm their existing charters and to grant them new rights that they were prepared to appoint speakers from rival urban authorities. Despite the fact that urban religious institutions were often in conflict with municipal administrations over issues of authority and jurisdiction, urban governments regularly hired members of the local clergy (who were often experts in the professional art of oratory) to deliver the harangue on their behalf. ${ }^{14}$ In 1461, Tours' échevins asked the town's bishop, Jean Bernars, to greet Louis XI in their name, while Rouen's rulers stated that it was necessary to have a member of the clergy speak on their behalf when Louis, duke of Orléans, and the queen, Anne of Brittany, entered the city $1492 .{ }^{15}$ Yet members of the clergy were not willing to deliver speeches that threatened their rights. Rouen's échevins asked the cathedral chanter, Michel Pétit, to greet Charles VIII in 1485 with a speech asking him to grant the city council the right to levy a subsidy to repair the fortifications. This was a crucial issue for Rouen in 1485 because soldiers were threatening a city as a result of the princely rebellion against the Crown known as the Guerre Folle. Nonetheless, the levying of a war subsidy alarmed Rouen's clergy who feared it would cause them to lose their exemption from lay taxation. Petit informed the municipal council that he would only greet the king if they abandoned their request for the subsidy. Not only did the échevins agree to Petit's demand, they also offered to support the requests the cathedral chapter planned to bring to the king following the entry. ${ }^{16}$ The fact that Rouen's municipal council was prepared to relinquish this lucrative subsidy (which the king would likely have awarded) highlights the importance it attached to the formal greeting. As Pétit was an eloquent speaker, Rouen's échevins were prepared to make concessions to secure his services and have the king confirm their rights, thus entrenching the municipal administration's power. Once municipal councils had acquired the assistance of expert speakers, they attempted to retain their services. Rouen hired Pierre Daré, the lieutenant-général of the bailliage, to deliver the harangues at royal entries for a quarter of a century. Not only was Daré a leading figure in Rouen's political and social hierarchy, he was also instrumental to

\footnotetext{
14 On the role of clerics in delivering speeches to the king on behalf of urban governments, see: Julien Brand, 'Foi, politique et information en Champagne au $\mathrm{XV}^{\mathrm{e}}$ siècle', Revue Historique 653 (2010), 72.

15 Aм Tours вв 10, fol. 344r; AD Seine-Maritime, Aм Rouen A 9, fol. 42r.

16 Beaurepaire, 'Charles VIII à Rouen', 282-83.
} 
the city's cultural life. ${ }^{17}$ As Daré was well versed in urban culture and practiced at making eloquent speeches, he was the perfect figure to deliver the harangue. Given his skills, Rouen's town council employed Daré at royal entries from 1492 to 1517 , during which time he greeted Anne of Brittany, Louis XII (three times) and Francis I. ${ }^{18}$ By enlisting Daré's services at successive entries, Rouen's échevins were able to draw on the proven talents of an expect speaker in order to obtain the confirmation of their rights.

As well as appointing expert speakers to be their mouthpiece, municipal councils hired professional writers to compose the text of the harangue. Although Daré greeted Louis XII in 1498, Rouen's échevins commissioned Bérenger Le Marchant (a canon in the city's cathedral chapter) to compose the text for the speech. ${ }^{19}$ Urban elites provided an overview of the items they wanted to include in the greeting, paying the writers to fashion these elements into a flattering and eloquent speech. At Châlons-en-Champagne, for example, the municipal council met the speechwriter to inform him of the matters he was to cover in the speech. ${ }^{20}$ Once the writer had completed the text, it was submitted to the municipal council for inspection. Speechwriters hired their services to various towns and an industry grew up around the staging of entries in sixteenth-century France, with poets and artists profiting from the fundamental role these ceremonies played in sustaining municipal power. ${ }^{21}$ In 1533 , Troyes' échevins employed Pierre Gringore to compose the greeting speech for Eleanor of Austria's entry. By this point, Gringore had almost two decades' worth of experience designing the entries of French queens. In particular, he devised the entire programmes for the Parisian entries of Mary Tudor (1514) and Claude of France (1517) on behalf of the capital's échevins. ${ }^{22}$ Town councils instructed experts such as Gringore to compose a concise harangue, as

17 Chas B. Newcomer, 'The Puy at Rouen', Publications of the Modern Language Association $3^{1}$ (1916), 216-17. For the Rouen puy see Denis Hüe, La poésie palinodique à Rouen (1486-1550) (Paris, 2002).

18 Anne of Brittany and Louis, duke of Orléans (later Louis XII), in 1492; Louis XII, 1498; Louis XII, 1508; Francis I, 1517 .

19 AD Seine-Maritime, AM Rouen A 9, fol. 54 r.

20 Sylvette Guilbert, ed., Registre de délibérations du Conseil de ville de Châlons-en-Champagne (1417-1421) (Châlons-en-Champagne, 2001), 190.

21 For these experts, see: Christian de Mérindol, 'Entrées royales et princières à la fin de l'époque médiévale: jeux de taxonomie, d'emblématique et de symbolique', in Christian Desplat and Paul Mironneau, eds., Les entrées: gloire et déclin d'un cérémonial (Biarritz, 1997), 43-44.

22 Babeau, Rois de France à Troyes, 38. For Gringore's Paris entries see: Cynthia J. Brown, ed., Les entrées royales à Paris de Marie d'Angleterre, 1514, et Claude de France, 1517 (Geneva, 
succinct greetings were invariably admired and thus more likely to persuade the recipient to act on the town's behalf. When Emperor Charles v entered Paris in 1540, the prévot des marchands, Augustin de Thou, delivered a speech that was lauded as 'elegant and succinct', while the greeting given to Charles, duke of Nemours and king of Navarre, at Montpellier in 1408 was praised on account of it being 'good, brief and honourable. ${ }^{23}$ Municipal councils hoped to avoid fatuous speeches because royal entries could be tests of endurance, which sometimes lasted as long as seven or eight hours. In 1463, Tournai's échevins ruled that Louis XI's greeting was to be brief, while Péronne's municipal council criticised the royal lieutenant for delivering an excessively long speech at Charles IX's entry in $1564 .{ }^{24}$ Urban governments frowned on lengthy speeches as they sapped the king's patience and good will, thus making him less disposed to receive urban petitions.

Town councils gave multiple speeches at joint entries. Although short greetings were favoured, the longest speech was typically reserved for the individual with the highest social status, who was normally the monarch. Yet a succession of royal minorities in Renaissance France meant that the king was not necessarily the most powerful person at the greeting. In these circumstances, municipal councils could adapt the greetings to give the longest speech to the person they deemed to be the most influential (and thus in the best position to advance their cause). When Charles Ix and Catherine de Medici entered Sens in 1564, the queen mother received the longest greeting speech. ${ }^{25}$ While Charles had proclaimed his majority after making his inaugural entry into Rouen in 1563 , his mother remained the effective ruler of the kingdom throughout the $1560{ }^{26}{ }^{26}$ By giving Catherine the longer greeting, the rulers of Sens acknowledged her power to confirm and extend the town's liberties. Indeed, it was the queen mother, rather than Charles IX, who had confirmed the privileges of Limoges in the previous year. ${ }^{27}$ As municipal administrations

2005); Michael Sherman, 'Pomp and Circumstances: Pageantry, Politics, and Propaganda during the Reign of Louis XII', Sixteenth Century Journal 9 (1978), 24-32.

23 G. Guiffrey, ed., Cronique du roy Françoys premier (Paris, 1860), 291; E. Alicot et al., eds., Thalamus parvus: le petit Thalamus de Montpellier publié pour la première fois d'après les manuscrits originaux (Montpellier, 1840), 446.

24 La Grange, 'Entrées des souverains', 48; BNF Collection de Picardie 54, fol. 248r.

25 Vaillancourt, Entrées solennelles, Charles $I X, 62$.

26 Hanley, Lit de Justice, 157-59. See also: Linda Briggs, "'Concernant le service de leurs dictes Majestez et auctorité de leur justice": Perceptions of Royal Power in the Entries of Charles IX and Catheine de Medicis (1564-1566)', in Mulryne, Aliverti and Testaverde, Iconography of Power, 47-50.

27 Ruben, Registres consulaires, Limoges, ii. 256-57. 
used extramural speeches to obtain the favour of those people who stood to benefit them the most, an individual's perceived value to urban governments could override customs regarding social status.

The pressure on urban administrations to make a speech that would win the favour of the most important people in the kingdom was exacerbated by a proliferation in the number of greetings delivered during the course of a royal entry. As the ceremony evolved over time, urban governments found that they had to compete with rival groups for the king's attention at the extramural greeting. Before the early fifteenth century, it was typically only the municipal council that offered a harangue during the extramural greeting. Yet other urban authorities began to deliver speeches during the fifteenth century in a bid to gain access to the ruler. The resurgence of the Hundred Years' War in 1415 led to an expansion of Lancastrian power in northern France. As towns in this region regularly changed hands during the early fifteenth century, other urban groups imitated civic leaders and used entries to develop links with the new ruler. During Henry vi's entry into Paris on 2 December 1431, the Parlement of Paris mimicked the municipal council by going beyond the city walls to formally welcome the Lancastrian monarch. The parlementaires rode out of the city as a corporate group and greeted the king at the mid-way point between La-Chappelle-St. Denis (where the municipal council traditionally met the monarch) and the gate of entry. In the run up to Henry's visit, the Parlement had unsuccessfully attempted to influence the actions of the royal council and obtain the security of their offices and salaries. The parlementaires' decision to greet Henry was a bid to gain direct contact with the monarch, who had largely spent his time in France in Calais and Rouen. ${ }^{28}$ We can detect a similar motivation behind the University of Paris's decision to join the extramural delegation at Charles viI's entry into the city in $1437 .{ }^{29}$ The city had returned to Valois rule in 1436 and the entry presented the University of Paris (which had backed the Lancastrian monarchy's claim to the French throne and supported Charles's disinheritance in 1420) with an opportunity to repair its relations with the

28 Alexandre Tuetey, ed., Journal de Clément de Fauquembergue, greffier du Parlement de Paris, 1417-1435, 3 vols (Paris, 1903-15), iii. 59, 61-62. See also: Lawrence Bryant, 'Configurations of the Community in Late Medieval Spectacles: Paris and London During the Dual Monarchy', in Barbara Hanawalt and Kathryn L. Reyerson, eds., City and Spectacle in Medieval Europe (Minneapolis, 1994), 12-18; Neil Murphy, 'Ceremony and Conflict in Fifteenth-Century France: Lancastrian Ceremonial Entries into French Towns, 1415-1431', Explorations in Renaissance Culture 39 (2014), 119-23. For the role of the Parlement of Paris in royal entries, see: Lawrence Bryant, 'Parlementaire Political Theory in the Parisian Royal Entry Ceremony', Sixteenth Century Journal 7 (1976), 15-25. 
Valois king. ${ }^{30}$ The opportunity to speak to the king in person at the extramural greeting allowed various urban groups to achieve a reconciliation with the Valois monarchy in the aftermath of the collapse of Lancastrian France. Yet these changes harmed civic administrations because they threatened to shift the focus of the event away from them.

By the early sixteenth century, French kings were accustomed to hear a range of speeches at their entries. The number of harangues varied from place to place and depended on the relationship between civic, royal and religious authorities. Unsurprisingly, the larger cities of the kingdom (which were often the location for political institutions) tended to have the greatest number of speeches. When Francis I entered Paris in 1526, he heard harangues from the city council, the royal officials of the Châtelet and the Cour des Aides, in addition to receiving greetings from the clergy. ${ }^{31}$ As Francis was entering Paris for the first time since his release from captivity in Madrid, the speeches allowed the capital's municipal, royal and religious authorities to renew their contact with the king. The proliferation in the number of harangues prompted Paris's civic council to try and maintain its position at the forefront of the extramural greeting. While the preparations for the Parisian entry of Charles VIII in 1484 led to protests about the order of the speeches from the prévot of Paris (who wanted to increase his prestige by delivering the first harangue), the municipal council retained its right to make the initial greeting. ${ }^{32}$ Although the Parisians kept their position at the forefront of the extramural reception, other municipal councils lost the right to greet the king first. At Rouen, the inclusion of greeting speeches from royal officers caused the city council to lose its precedence in some extramural greetings during the early sixteenth century. When Louis XII entered the city in 1508, the municipal council's harangue came after the greeting delivered by Louis de Brézé, the grand sénéchal, who was accompanied by a large body of Norman nobles. ${ }^{33}$ This meant that the initial character of Louis XII's reception at Rouen was noble rather than bourgeois. Given this loss in precedence, Rouen's échevins hired experts (such as Pierre Daré) to develop memorable and eloquent speeches that would keep the focus of the extramural greeting on the civic administration.

3o Jean Favier, Paris au XVe siècle, 1380-1500 (Paris, 1974), 229-30. The University of Paris had developed close links with the Lancastrian administration between 1419 and 1436: Guy Thompson, Paris and its People: The Anglo-Burgundian Regime 1420-1436 (Oxford, 1991), 7.

31 G. Fagniez, ed., Livre de raison de M. Nicholas, avocat au Parlement de Paris 1519-1530 (Paris, 1885), 102.

32 Godefroy, Ceremonial François, i. 225.

33 AD Seine-Maritime, AM Rouen A 10, fol. 46r. 
Although greeting speeches have been dismissed as 'programmed, repetitive and sycophantic', they played an essential role in the confirmation of municipal liberties, which was the most important element of the extramural greeting for townspeople. ${ }^{34}$ When Francis I entered Toulouse in 1533, the capitoul who delivered the speech asked the king to confirm the city's privileges. Francis responded to this request by saying: 'you have always been loyal and obedient to my predecessors and me. I know this well and thank you for your good wishes, and with regards to your privileges and liberties I will keep you in them. ${ }^{35}$ The intimate nature of the urban elite's interaction with the monarch was crucial to the success of the extramural greeting. Rudolf Schlögl developed the idea of 'participation societies' (Anwesenheitsgesellschaften); namely, that pre-modern urban elites preferred to engage in politics by means of face-to-face meetings rather than through written documents. ${ }^{36}$ Urban liberties were confirmed by the words and gestures the king delivered during his face-to-face encounter with the municipal delegation. ${ }^{37}$ Although municipal councils hired notaries to draw up a record of the king's confirmation of their liberties, this was principally for archival purposes. ${ }^{38}$ The textual account of the event provided civic councils with a record of the king's oath which they could produce if their rights were challenged in the future. When municipal

34 Vaillancourt, 'Introduction', in Entrées solennelles, Charles IX, 16.

35 AM Toulouse AA 5/97. See also: AA 83, fols. 1-12v.

36 Rudolf Schlögl, 'Vergesellschaftung unter Anwesenden. Zur kommunikativen Form des Politischen in der vormodernen Stadt', in Rudolf Schlögl, ed., Interaktion und Herrschaft: Die Politik der frühneuzeitlichen Stadt (Constance, 2004), 9-6o. On this point, see also: Gadi Algazi, 'Doing Things with Gifts', in Gadi Algazi, Valentin Groebner and Bernhardt Jussen, eds., Negotiating the Gift: Pre-Modern Figurations of Exchange (Göttigen, 2003), 23; Michael Clanchy, From Memory to Written Record: England 1066-1307 (London, 1979), chapters eight and nine; Beat Kümin, The Communal Age in Western Europe, c.110o-180o (Basingstoke, 2013), 73. For the importance of spoken communication for urban governments, see: Thierry Dutour, 'L'élaboration, la publication et la diffusion de l'information à la fin du Moyen Âge (Bourgogne ducale et France royale)', in Didier Lett and Nicholas Offenstadt, eds., Haro! Noël! Oyé! Pratiques du cri au Moyen Âge (Paris, 2003), 152-54.

37 This is in contrast to the petitions for additional liberties, which were dependent on the receipt of written confirmation (see chapter two).

38 For notaries recording the confirmation of municipal liberties at entries, see: E. Lecesne, Histoire d'Arras depuis les temps plus recules jusqu'en 1789, 2 vols (Arras, 1880), i. 399; Guenée and Lehoux, Entrées royales françaises, 85-86, 176-77; Rivaud, Entrées princières, 113-21; Olivier Rouchon, 'Rituels publics, souveraineté et identité citadine: les cérémonies d'entrée en Avignon (XVIe-XVII ${ }^{\mathrm{e}}$ siècles)', Cahiers de la Méditerranée 77 (2008), 55. On this point, see also: Timothy Watson, 'Friends at Court: The Correspondence of the Lyon City Council, c. 1525-1575', French History 13 (1999), 283. 
councils sent delegations to court at the beginning of a new monarch's reign to swear loyalty to the incumbent king, their words and gestures were the essential parts of the ritual. A delegation from Lyon that travelled north to swear loyalty to Henry II in June 1547 asked Paris's échevins if they had received a charter confirming their homage to the new king. In response, the Parisians told Lyon's delegation that 'they were not accustomed to make a letter or charter of this homage, as they only made the reverence and loyalty [while] kneeling. ${ }^{39}$ In other words, swearing an oath was a physical act rather than a written one. It brought the monarch into close physical proximity to municipal leaders, who used this interaction as proof of their privileged relationship with the monarch.

The intimate nature of the extramural greeting provided civic councils with a rare moment of direct interaction with the king during the public entry, while the reciprocal exchange of greetings encouraged the creation of a friendly relationship between the monarch and the urban elite. Charles viII responded to the greeting speech at his entry into Abbeville in 1493 by saying he 'held the said inhabitants for his good, true and loyal subjects and that they had been and always would be in [his] recommendation. ${ }^{40}$ Similarly, after Francis I heard the welcoming speech at Béziers in 1533 'he thanked them heartily'.41 The public exchange of verbal greetings with the king reinforced the municipal council's legitimacy to rule. As the trend to have liberties ratified at court at the beginning of a monarch's reign meant that the confirmation of urban rights was gradually eroded from the extramural encounter (see below), the exchange of greetings became focused on underpinning the town council's authority. The verbal exchange emphasised the urban elite's relationship with the king, from whom their power derived. For example, Charles IX replied to the greeting from Narbonne's consuls in 1565 by saying: 'I order you [the consuls] to administer justice to my subjects', following which he confirmed their privileges.$^{42}$ Charles's speech underscored the municipal council's authority to administer justice on his behalf by emphasising the strong links that existed between the king and the municipal elite. With the outbreak of the Wars of Religion, the monarch used his speech to buttress the authority of Catholic urban elites in regions such as Languedoc where royal authority was contested.

39 AM Lyon в B 66, fol. 50v.

40 Ledieu, 'Charles VIII à Abbeville', 56.

41 Domarion, Entrée François Ier, Béziers, 43.

42 Vaillancourt, Entrées solennelles, Charles IX, 178-79. For Charles IX's confirmation of Narbonne's privileges, see also: AM Narbonne AA 66. 
In return for granting powers to municipal administrations, the king expected civic leaders to secure their towns for the Crown.

As well as seeking the ratification of their existing liberties, municipal councils also used the harangue to set the scene for their petitions for new rights. ${ }^{43}$ When Louis XI entered Brive-la-Gaillarde on 27 June 1463 , the speaker asked the king to support the town 'in pity and take our poverty and small size gladly' ${ }^{44}$ The speech prepared the ground for the economic liberties the municipal council requested from Louis after the entry, which were designed to restore Brive's prosperity. Furthermore, extramural greeting speeches were linked to the gift exchange that followed the public entry. When Charles $\mathrm{V}$ entered Poitiers on 9 December 1539, the consuls asked him to remember the town in the future ('en souvenance pour l'advenir'). ${ }^{45}$ As soon as the municipal council offered its gifts to the emperor in his private chambers following the entry, Charles replied that he would remember the town ('il en auroit souvenance'), thus referencing the request he received in the extramural greeting and linking the two acts. ${ }^{46}$

Some kings exhibited heightened emotions when responding to urban speeches. For Johan Huizinga the 'extreme excitability of the medieval soul' and 'vehement passion possessing princes and peoples alike' was representative of a child-like sensibility. ${ }^{47}$ The Dutch historian characterised the Middle Ages as an era of uncontrolled emotions, when crowds burst into apparently spontaneous tears during ceremonial occasions. Huizinga stated that 'this general facility of emotions, of tears and spiritual upheavals, must be borne in mind in order to conceive fully how violent and high-strung was life at the period. ${ }^{48}$ Following Huizinga's lead, Norbert Elias believed that the unrestrained emotional behaviour that typified the Middle Ages was brought to heel in the mid-sixteenth century when members of modern 'civilized' societies began to regulate their emotional behaviour. ${ }^{49}$ Historians such as Jeroen Duindam and Barbara Rosenwein have overturned the long-lasting influence

43 See, for example: Beaurepaire, 'Charles VIII à Rouen', 282.

44 Guenée and Lehoux, Entrées royales françaises, 179.

45 Rivaud, Entrées princières, 205-6.

46 Rivaud, Entrées princières, 205-6, 221.

47 Johan Huizinga, The Waning of the Middle Ages, trans. F. Hopman (Toronto York, 1924), 11.

48 Huizinga, Waning of the Middle Ages, 9.

49 Norbert Elias, The Civilizing Process: Sociogenetic and Psychogenetic Investigations, revised edition, trans. Edmund Jephcott (Oxford, 2000), 168-72. On Elias and emotions, see: Robert van Krieken, 'Norbert Elias and Emotions in History', in David Lemmings and Ann Brooks, eds., Emotions and Social Change: Historical and Sociological Perspectives (New York, 2014), 19-42. 
of Huizinga and Elias, while others have shown how the populations of medieval and early modern Europe controlled and displayed their emotions. ${ }^{50}$ As early as 1941, Lucien Febvre highlighted the connections between rituals and the presentation of emotions. ${ }^{51}$ More recently, Gerd Althoff has demonstrated how the symbolic representation of emotion formed a key element of ritualised actions. ${ }^{2}$ Demonstrative behaviour and the externalisation of emotions were crucial tools of communication for pre-modern monarchs. In particular, the degree to which a king laughed in a formal context was an important medium of communication. As Sara Beam, Quentin Skinner, Keith Thomas and others have shown, there were a number of meanings associated with joy and laughter in early modern Europe. ${ }^{53}$ However, Denis Crouzet has recently asserted that under Francis I laughter and power... were no longer intrinsically associated in the intellectual osmosis that was one of the arts of government of Louis XII.54 Yet Crouzet overstates the decline in the use of laughter for political purposes by the monarchs of sixteenth-century France. Although Francis I clamped down on satire and farce at the beginning of his reign, he used laughter for communicative purposes during ceremonial

50 Jeroen Duindam, Myths of Power: Norbert Elias and the Early Modern Court (Amsterdam, 1994); Barbara H. Rosenwein, Emotional Communities in the Early Middle Ages (Ithaca and London, 2007). For other influential studies of the role of emotions in history, see: Elina Gertsman, ed., Crying in the Middle Ages: Tears of History (Abingdon, 2012); Barbara H. Rosenwein, ed., Anger's Past: The Social Uses of an Emotion in the Middle Ages (Ithaca and London, 1998); idem, 'Worring about Emotions in History', American Historical Review 107 (2002), 821-45.

51 Lucien Febvre, 'Sensibility and history: how to reconstitute the emotional life of the past', in Peter Burke, ed., A New Kind of History: From the Writings of Febvre, trans. K. Folca (London, 1973), 15 .

52 Gerd Althoff, Family, Friends and Followers: Political and Social Bonds in Medieval Europe, trans. Christopher Carroll (Cambridge, 2004); idem, Otto III, trans. Phyllis G. Justice (University Park, 2003).

53 Sara Beam, Laughing Matters: Farce and the Making of Absolutism in France (Ithaca, 2007); Laurent Joubert, Treatise on Laughter, trans. Gregory David de Rocher (Alabama, 1980); Quentin Skinner, 'Hobbes and the Classical Theory of Laughter' in Tom Sorell and Luc Foisneau, eds., Leviathan After 350 Years (Oxford, 2004), 142-49; Matthew Steggle, Laughing and Weeping in Early Modern Theatres (Aldershot, 2007), 11-23; Keith Thomas, 'The Place of Laughter in Tudor and Stuart England', Times Literary Supplement (21 Jan., 1977), 77-81.

54 D. Crouzet, 'From Christ-like king to antichristian tyrant: a first crisis of the monarchical image at the time of Francis I', in Graeme Murdock, Penny Roberts and Andrew Spicer, eds., Ritual and Violence: Natalie Zemon Davis and Early Modern France (Past and Present Supplement, 2012), 229 . 
events. When Francis entered Dijon in 1530, the mayor, Pierre Morin, delivered an especially honourable greeting, in response to which the king 'laughed very heartedly'.55 Indeed, Francis displayed an especially heightened sense of joy in response to the extent of the townspeople's acclamations at his entry. The capability to articulate joy in public at appropriate times was an important skill for members of pre-modern royal and princely courts. Philippe de Commynes tells us how the members of Louis XI's entourage made a show of great delight for the king's benefit when the news of Charles the Bold's death reached the Valois court. ${ }^{56}$ Likewise, exhibiting joy during a ceremonial entry in sixteenth-century Europe allowed rulers to make a forceful political statement, particularly because a resurgence of interest in antique triumphs had encouraged Renaissance monarchs to imitate Roman emperors by appearing emotionless at their entries. ${ }^{57}$ Writing of Louis XII's entry into Cremona in 1509 , Jean Marot noted that 'the king was like Caesar in the gestures he displayed'.58 By this sixteenth century, appearing as Caesar meant acting emotionless. A vivid example of this is seen when we examine the entry of the future Philip II into the former French city of Tournai in 1549. According to a contemporary account, the échevins included a dramatic performance based on the

55 Gouvenain, Inventaire sommaire, Dijon, i. 57.

56 Philippe de Commynes, Mémoires, ed. Philippe Contamine (Paris, 1994), 324. Lawrence Bryant, "What face to put on": extravagance and royal authority in Louis XI's ceremonies', in John J. Contreni and Santa Casciani, eds., Word, Image, Number: Communications in the Middle Ages (Galluzzo, 2002), 319-20.

57 Ammianus Marcellinus writes that when entering Rome in 357 Emperor Constantius II was 'calm and imperturbable' and 'as if his neck were in a vice, he kept the gaze of his eyes straight ahead, and turned his face neither to right nor to left, but... neither did he nod when the wheel jolted nor was he even seen to spit, or wipe of rub his face or nose, or move his hands about': Ammianus Marcellinus, History, trans. J. C. Rolfe, 3 vols (London, 1935-40), i. 247. For this entry, see: Marianne Sághy, 'The adventus of Constantius II to Rome 357 AD', in Balázs Nagy and Marcell Sebők, eds., ... The Man of Many Devices, Who Wandered Full Many Ways ... Festschrift in Honor of János Bak (New York, 1999), 148-6o.

58 Jean Marot, Sur les deux heureux voyages de Gennes et de Venise, victorieusement mys a fin par le Tres Crestien Roy Loys douzième de ce nom. Alors poète de la Reyne Anne, duchesse de bretaigne, et depuis valet de Chambre du Tres Chrestien Roy Françoys premier de ce nom (Lyon, 1537), 105, cited in: Josèphe Jacquiot, 'De l'entrée de César à Rome à l'entrée des rois de France dans leurs bonnes villes', in J. R. Mulryne and M. Shewring, eds., Italian Renaissance Festivals and their European Influence (Lewiston, 1992), 257. For this entry, see: Carlo Alfeni, 'Narratione dell entrata in Cremona di Lodovico XII re de Francia in una visita di Luigi alla città di Cremona, 24-26 giuno 1509', Archivo Storico Lombardo, 4th series, 8 (1907), 152-66; Nichole Hochner, Louis XII: les dérèglements de l'image royale, 1498-1515 (Seyssel, 2006), 118. 
biblical story of Judith and Holofernes in the entry. In order to give a degree of realism to the event, they had a criminal under sentence of death play the role of the Persian general and have his head severed from his body as Philip rode past. Despite being sprayed with the blood spurting out from the victim's neck, this source claims that the prince remained emotionless and impassive. ${ }^{59}$ While scholars have debated the authenticity of this account of Philip's entry, it nonetheless highlights the fact that sixteenth-century princes were expected to appear emotionless at their entries. ${ }^{60}$ Philip's ability to appear imperturbable even when sprayed by the blood of a common criminal served as a means to manifest his imperial character and endorse the Habsburg family's claim to be the legitimate successors of the Roman emperors.

The articulation of emotion at an entry in sixteenth-century Europe was a powerful means of communication for rulers precisely because it went against contemporary expectations of royal behaviour. Hence, a king's exhibition of heightened emotion was a conscious gesture he deployed to achieve a particular goal. Certainly, Francis I's deliberate display of laughter and joy at Dijon can be explained by the political circumstances of the entry. In order to secure his release from captivity, by the terms of the treaty of Madrid (1526) Francis agreed to cede the duchy of Burgundy to Charles v. Despite leaving his sons in Spain as hostages, Francis reneged on this promise as soon as he returned to France. The king justified his actions by emphasising the extent of his popularity with the inhabitants of Burgundy, who, he asserted, overwhelmingly wanted to remain under French rule. This claim was supported by the Estates of Burgundy, which voted to remain part of France when they met at Dijon on 4 June $1526 .{ }^{61}$ As the 1530 entry was Francis's first visit to Dijon since his release from captivity, his display of joy at the extramural greeting allowed him to highlight his attachment to the duchy and thank its ruling elites for their support.

Fédéric Faber, Histoire du théâtre français en Belgique depuis son origine jusqu’à nos jours d'après des documents inédits reposant aux archives générales du royaume, 2 vols (Paris and Brussels, 1880), ii. 14-15. Paul Rolland, Histoire de Tournai (Tournai, 1956), 194.

6o For the debate on this topic, see: Jody Enders, 'Medieval Snuff Drama', Exemplaria 10 (1998), 171-206; idem, The Medieval Theater of Cruelty: Rhetoric, Memory, Violence (Ithaca, 2010), 205-10; Margaret E. Owens, Stages of Dismemberment: The Fragmented Body in Late Medieval and Early Modern Drama (Newark, 2005), 24-26, 121.

61 R. J. Knecht, The Rise and Fall of Renaissance France, 1483-1610, 2nd edition (Oxford, 2001), 127. See also: H. Hauser, 'Le traité de Madrid et la cession de la Bourgogne à Charles Quint. Étude sur le sentiment national en 1525-26', Revue bourguignonne 22 (1912), 1-182; Mack P. Holt, 'Burgundians into Frenchmen: Catholic Identity in Sixteenth-Century Burgundy', in Michael Wolfe, ed., Changing Identities in Early Modern France (London, 1997), 351. 
French kings made a range of other honourable gestures to urban elites when they wanted to indicate their regard for them. For example, Louis XI underscored his favour for civic councillors by taking off his hat and gloves when responding to municipal speeches. ${ }^{62}$ The removing of a hat was an important gesture of respect in pre-modern Europe, particularly when made by a monarch. In her life of Charles v, Christine de Pisan stated that the French king honoured those who came to greet him by removing his headwear. ${ }^{63}$ By the sixteenth century, manuals of civility stressed the importance of taking off one's hat in the presence of a social superior, particularly when entering their house. It was a mark of great esteem for the king to make this gesture to his social inferiors when greeting urban administrations at the entrance to their jurisdiction. ${ }^{64}$ Urban governments also used sacred objects (such as crosses and relics) to encourage the king to behave deferentially. ${ }^{65}$ Although relics were present in French entries from the fourteenth century, they became particularly prominent during the reign of Louis XI, probably because he had a strong reverence for sacred objects. ${ }^{66}$ Towns generated wealth through the possession of relics because the presence of holy objects drew pilgrims (and their money) to urban centres. This stream of revenue was especially important for smaller towns, which often lacked a significant commercial or industrial sphere. The monarch was the wealthiest and most powerful of these pilgrims and the gifts he provided were of considerable economic benefit for urban communities. Indeed, the possession of especially significant sacred objects encouraged French monarchs to give generously to urban communities. When Louis XI visited Le Puy in 1476, he granted the population a general remission of taxes for ten years as part of his offerings to the cathedral's renowned shrine to the Virgin Mary. ${ }^{67}$ Aware of the power of relics to persuade king to grant liberties, the rulers of towns which lacked first-rate sacred objects (such as

62 Am Toulouse AA 3/277; Jean-Paul Lartigue, Louis XI en Bas-Limousin, 1463 (Brive, 1963), 11.

63 Christine de Pisan, Le Livre des fais et bonnes meurs du sage roy Charles V, ed. S. Solente, 2 vols (Paris, 1936), ii. 198; BNF français 1182, fol. 21r; Bryant, 'Medieval Entry Ceremony', 100.

64 Herman Roodenburg, "The "hand of friendship": shaking hands and other gestures in the Dutch Republic', in Jan Bremmer and Herman Roodenburg, eds., A Cultural History of Gesture from Antiquity to the Present Day (Cambridge, 1993), 164.

65 For the visibility of relics and the importance of their location in ceremonies, see: Edward Muir, 'The Eye of the Procession: Ritual Ways of Seeing in the Renaissance', in Nicholas Howe, Ceremonial Culture, 129-50; Richard C. Trexler, Public Like in Renaissance Florence (Ithaca and London, 1980), 57-61.

66 Pierre Champion, Louis XI, 2 vols (Paris, 1927), 203-13; Paul Murray Kendall, Louis XI (London, 1971), 365-67; Jean Favier, Louis XI (Paris, 2001), 63-71.

67 Potter, Nation State, $15^{8-59 .}$ 
Le Puy's statute of the Virgin Mary) instead brought all their relics together to harness their collective spiritual power. When Louis entered Brive-la-Gaillarde, for example, the municipal council displayed the town's collection of relics outside the walls for the extramural confirmation of liberties. The items were placed in front of the Franciscan monastery (which lay a short distance outside the gate of entry) and Louis knelt before them during the greeting. ${ }^{68}$

Although Bernard Chevalier found that French civic administrations avoided identifying themselves with a patron saint, nonetheless for a royal entry they harnessed the power of those relics that embodied local identity. 69 Amongst the relics exhibited for Louis XI at Brive was the head of Saint Martin (the town's patron saint); when Francis I entered Marseille in 1516, the cloak of Saint Lazarus (believed to be the first bishop of the city) was shown to the king during the extramural greeting. This relic had resided in the city's abbey of Saint Victor since the fifth century and it was an emblem of civic pride. ${ }^{70}$ At Charles VIII's entry into Abbeville in June 1493, the head of Saint Wulfran (after whom the town's principal church was named) was brought out and displayed in the extramural procession for the king, while Limoges used the head of Saint Martial in their entries (the city's cathedral was named in his honour)..$^{71}$ Devotional objects were at their most powerful when they were attached to confirmation of urban liberties. At Toulouse, Louis XI kissed the cross the townspeople offered him and then confirmed the city's liberties. ${ }^{72}$ Moreover, municipal governments used relics to encourage the king to kneel before them. For example, Charles vir knelt before the relics brought out of

68 Henri Delsol, Le Consulat de Brive-La-Gaillarde: essai sur l'histoire politique et administrative de la ville avant 1789 (Brive, 1936), 112.

69 According to Chevalier, saintly relics 'remained the exclusive property of ecclesiastical institutions', yet as we see they were also used on the behalf of municiapal governments during entries: Bernard Chevalier, 'La religion civique dans les bonnes villes: sa portée et ses limites. Le cas de Tours', in Andre Vauchez, ed., La religion civique à l'époque médiévale et moderne: chrétiénté et islam: actes du colloque (Rome, 1995), 341.

$70 \quad$ Guenée and Lehoux, Entrées royales françaises, 181; Louis Barthélemy, 'Entrée du roi François Ier à Marseille en 1516 raconter par un notaire', Mémoires de l'Académie de Marseille (1884-85), 220; Nöel Coulet, 'Dévotions communales: Marseille et saint Victor, saint Lazare et saint Louis (XIII ${ }^{\mathrm{e}}-\mathrm{XV}^{\mathrm{e}}$ siècle)', in A. Vauchez, ed., La religion civique à l'époque médiévale et moderne (Chrétienté et Islam) (Rome, 1995), 119-33.

71 Ledieu, 'Charles VIII a Abbeville', 55; Ruben, Registres consulaires, Limoges, ii. 111-14. Compiègne used part of the True Cross during the extramural greeting: AM Compiègne B в 18, fols. 99r-10or. 
Limoges for his entry in $1439 .{ }^{73}$ As we saw at the beginning of the book, the rulers of La Rochelle were particularly adept at using devotional objects to compel the king to kneel. To recap, when Louis XI prepared to enter the city on 24 May 1472, the consuls informed him that it was customary for French kings to confirm the city's liberties during the extramural greeting. Louis then got down from his horse, knelt in front of the mayor (who remained standing) and swore to maintain the city's rights with his hands on the gospels. ${ }^{74}$ La Rochelle's government used sacred items to create a temporary sacred space at the gate of entry for the swearing of oaths, while the king's deferential gestures reinforced the mayor's authority in front of the townspeople who gathered to watch the entry. The French king's urban subjects were accustomed to see him kneeling during a royal entry. An Italian witness of Henry II's entry into Reims in 1547 recounts how the king got down on his knees and 'with his cap in hand, before entering [the cathedral], swore on the hand of the archbishop a certain promise that because of the great noise I could not hear, but they said it was customary for all kings [to take the oath] in this situation. ${ }^{75}$

The rulers of cities that came under French rule during the Italian wars were also able to use a ceremonial entry to encourage French monarchs to confirm their privileges. Under normal circumstances, the presence of a foreign king at the head of an army alarmed urban governments and threatened their privileges. Yet the French monarchy was initially seen as the defender of local rights and privileges in Italy. ${ }^{76}$ When Charles arrived at Florence in

73 Maurice Ardant, 'Réations des passages de Charles VII à Limoges en 1438 et 1442', Bulletin de la Société archéologique et historique du Limousin 5 (1854), 56; Alfred Leroux, 'Passages de Charles VII et du dauphin Louis à Limoges en 1439, des mèmes et de la reine de France en 1442', Bibliothèque de l'École de Chartes 56 (1885), 305.

74 The oath taking took place beside the church of Marie de Compuis, which reinforced the sacred character of the event: Rivaud, Entrées princières, 117-21. Spanish monarchs also kneeled when confirming local rights as part of a royal entry: Ruiz, A King Travels, 132. As Miguel Raufast Chico has shown, entries in Aragon also provided a moment for negotiation between the king and the city: Miguel Raufast Chico, ' $¿$ Negociar la entrada del rey? La entrada real de Juan II en Barcelona (1458)', Anuario de Estudios Medievales 36 (2006), 295-333; idem, 'La entrada real de Martín el Joven, rey de Sicilia en Barcelona (1405): Solemnidad, economía y conflicto', Acta historica et archaeologica mediaevalia 27-28 (2006), 89-119. For the gesture of kneeling, see: Jean-Claude Schmitt, La raison des gestes dans l'Occident médiéval (Paris, 1990), 295-302.

75 Hughes Kraft, L'entrée du Roi Très Chrétien Henri II dans la ville de Reims et son couronnement. Traduction de l'italien (Reims, 1913), 281.

76 Knecht, Renaissance France, 39-40. At Charles VIII's entry into Pisa, the citizens used the greeting speech to ask the king to defend the city's liberties against Florence: André de la Vigne, Le Voyage de Naples, ed. Anna Slerca (Milan, 1981), 200. 
November 1494, the townspeople placed the inscription 'Keeper and liberator of our freedom' (Conservateur et liberateur de nostre liberté) on the gate of entry because his actions had brought an end to Medici rule in the city. ${ }^{77}$ By confirming the liberties of Italian cities, French monarchs were able to pose as the defenders of local privileges rather than foreign conquerors. For example, Louis XII took an oath 'to maintain and keep the rights, franchises and liberties of his town of Genoa' in the Cathedral of Saint Lorenzo in 1502. ${ }^{78}$ As oaths were taken in front of the great altar, the king was expected to kneel when swearing to maintain local privileges. Moreover, merchants made commercial contracts at altars in the presence of relics in order to create the trust necessary for successful business relationships. ${ }^{79}$ Urban elites hoped to profit from the contract they entered into with the king, who confirmed the rights that underpinned the financial prosperity of civic leaders and sustained their position at the pinnacle of urban society.

At Dijon, the use of an altar and the presence of an abbot and the gospels transformed the confirmation of provincial rights into a spiritual oath. In 1548, the abbot of Saint-Bénigne, Claude de Longwy, took the ducal ring and placed it on Henry II's finger during the ceremony, symbolising the union between the monarch and the province. ${ }^{80}$ In return for the confirmation of the liberties of both the city and Burgundy, Dijon's mayor swore an oath of loyalty to the king on behalf of the wider population. While the oath taking at Dijon endorsed the Valois monarchy's right to rule a region that was also claimed by

77 Mitchell, Majesty of State, 64.

78 Godefroy, Cérémonial françois, i. 683, 708. When Louis XII re-entered Genoa in 1507 after he had suppressed its rebellion, he publicly tore up and then burned the book detailing these privileges, following which he appointed a French governor (Raoul de Lannoy) to rule the city: Mitchell, Majesty of State, 93.

79 Trexler, Public Life in Renaissance Florence, 2.

$80 \quad$ Catherine Chédeau, 'Les préparatifs des joyeuses entrées d'Henri II (1548) et de Charles IX (1564) à Dijon: l'art, les fêtes et la ville', Mémoires de l'Académie des sciences, arts et belleslettres de Dijon 137 (1999-2000), 192-93; L. Chomton, Histoire de l'église de Saint-Bénigne de Dijon (Dijon, 1900), 457. This ring was used at the entries of the dukes of Burgundy in the fifteenth century: Pierre Quarré, 'La "joyeuse entrée" de Charles le Téméraire à Dijon en 1474, Bulletin de la classe des beaux-arts. Académie royale de Belgique $5^{1}$ (1969), 336. Likewise, a ring was placed on the finger of Charles of France, duke of Normandy, when he took an oath to safeguard the rights and liberties of the duchy following his inaugural entry into Rouen in 1465. After Louis XI re-imposed his rule over the duchy, he sent the constable of Saint-Pol to Rouen to publicly break the ring: Lettres sur la ville de Rouen ou précis de son histoire topographique, civile, ecclésiastique et politique depuis son origine jusqu'en 1826 (Rouen, 1826), 523 . 
the Habsburgs, it also reinforced the authority of Dijon's mayor, who took the oath on behalf of all the duchy's inhabitants. As proximity to the king was a mark of power, the reciprocal oath taking raised the profile of the mayor, who knelt next to the king throughout the event. Participation in the oath-taking ceremony was restricted to the most influential people in the kingdom. When Philibert de Beaujeu, mayor of Dijon, swore an oath of loyalty to Henry II (who had just confirmed the town's privileges) in front of the great altar at Saint Bénigne in 1548, he did so in the presence of the chancellor, François Olivier, the cardinals of Guise, Châtillon, du Bellay and Saint-André, the constable, Anne de Montmorency, the grand écuyer de France, Claude Gouffier, the governor of Burgundy, Claude of Lorraine, as well as Claude Bourgeois, one of the leading members of Henry II's royal council. ${ }^{81}$ These men occupied the highest political offices in the kingdom and held great influence with the king. The reciprocal oath taking at Dijon united the monarch, his principal household officials, the provincial governor and the town council around the altar, consolidating the bonds between them. In addition to the spiritual benefits of using a religious building for the oath taking, the enclosed setting of an abbey or church allowed municipal councils to restrict the number of people present at the event. Francis I reconfirmed Marseille's liberties on 24 January 1516 (two days after his entry) in the church of Notre-Dame-des-Accoules. The setting of the event was significant, as the church was located next to the town hall and expressed municipal power. Francis swore to respect the privileges of Marseille in the presence of the princes who accompanied him, as well as the chancellor and the civic council. ${ }^{82}$ As the consuls had already sent a delegation to court in 1515 to have the city's liberties ratified, they did not ask Francis to confirm their rights during the extramural greeting. Accordingly, the pre-entry ratification of municipal liberties allowed Marseille's consuls to devise an intimate post-entry reconfirmation ceremony that strengthened their relationship with the king and the most powerful people in the kingdom by excluding all other members of urban society, especially those groups and individuals who posed a threat to their authority.

The opportunity to develop a lasting covenant with the king was particularly important for urban administrations during times of conflict. Amiens' position on the strategically important Somme river placed its inhabitants at the centre of the Franco-Burgundian conflicts of the 146os and 1470s. On 4 January 1471, Antoine de Chabannes arrived outside Amiens at the head of an army and

\footnotetext{
81 Chédeau, 'Préparatifs', 192-93.

82 E. Baux, V.-L. Bourilly and P. Mabilly, 'Le voyage des reines et de François Ier en Provence et dans la vallée du Rhone (déc. 1515-févr. 1516)', Annales du Midi 16 (1904), 52.
} 
ordered the city to surrender to Louis XI or face destruction. ${ }^{83}$ At a hastily convened meeting of the town council, the échevins decided to open their gates to the count rather than risk a sack. Chabannes entered Amiens the following day and the townspeople took an oath of loyalty to the king during a service held in the cathedral, in return for which the échevins received royal letters confirming their rights and liberties. ${ }^{84}$ On 27 May 1471 Amiens' civic council received a further letter from Louis XI promising that he would never separate Amiens from the French Crown. ${ }^{85}$ While the king's assurances were designed to maintain the loyalty of frontier cities, which could feel remote from the Crown, nonetheless seven months after guaranteeing the people of Amiens that they would never be separated from the Crown, the municipal council heard rumours that the city was to be returned to Charles the Bold, duke of Burgundy. ${ }^{86}$ This was disastrous news for the townspeople, as they had opened their gates to a French army and taken an oath of loyalty to the duke's enemy, Louis XI. The potential consequences of this action terrified the councillors, who were afraid that the return of Burgundian rule would lead to their 'total destruction'. ${ }^{87}$ Urban communities feared Charles the Bold because of his proclivity for destroying cities such as Dinant (1466) and Liège (1468). When Dinant fell in August 1466, Charles drowned eight hundred townspeople. The city was then burned and its fortifications demolished, while Liège was systematically destroyed. ${ }^{88}$

83 AM Amiens B B 11, fols. 4r-4v. For the destruction of towns see: Peter Arnade, 'Spanish Furies: The Siege and Sack of Cities in the Dutch Revolt', in Peter Arnade and Michael Rocke, eds., Power, Gender and Ritual in Europe and the Americas. Essays in Memory of Richard C. Trexler (Toronto, 2008), 169-88; Marc Boone, 'Destroying and Reconstructing the City: The Inculcation and Arrogation of Princely Power in the Burgundian-Habsburg Netherlands (14th-16th centuries)', in M. Gosman, A. Vanderjagt and J. Veenstra, eds., The Propagation of Power in the Medieval West: Selected Proceedings of the International Conference, Groningen 20-23 November 1996 (Groningen, 1997), 1-33; Marc Boone and Heleni Porfyriou, 'Markets, squares, streets: urban space, a tool for cultural exchange', in Donatella Calabi and Stephen Turk Christensen, eds., Cultural Exchange in Early Modern Europe. Volume II: Cities and Cultural Exchange in Europe, 1400-1700 (Cambridge, 2007), 229-35.

84 Ам Amiens в в 11, fol. 4v; Chronique scandaleuse, i. 254-55; Édouard Maugis, Essai sur le régime financier de la ville d'Amiens du XIVe à la fin du XVIe siecle (1356-1588) (Paris, 1899), 406, 412.

85 AM Amiens B B 11, fols. $5 \mathrm{r}$ and 16v (quote on fol. 16v).

86 Aм Amiens Bв 11, fol. 51r.

87 Aм Amiens в в 11, fols. 1r-1v, 26r (quote on fol. 26r).

88 Richard Vaughan, Charles the Bold: The Last Valois Duke of Burgundy (London and New York, 2003), 34-35; Robert Douglas Smith and Kelly DeVries, The Artillery of the Dukes of Burgundy 1363-1477 (Woodbridge, 2005), 155-56. 
The distribution of songs and poems across the Burgundian dominions spread news of the fate of Liège and Dinant. ${ }^{89}$ Indeed, Amiens' councillors feared that their town would be destroyed 'as they had done to the town of Dinant, which they [the Burgundians] had burnt with fire and flame'. The matter was so serious that the mayor of Amiens, Philippe de Morvilliers, journeyed to Tours to plead the town's case before the king. Philippe was granted an audience with Louis, who assured him that he would never separate Amiens from the Crown 'because he knew well that all the bourgeois and habitants of this town were good and loyal to him and the Crown of France'. 90

As royal guarantees were crucial for the well being of urban populations (especially during periods of political instability), municipal elites required the king to swear an oath during a royal entry affirming that he would never alienate them from the Crown. Urban administrations asked the monarch to take this oath because they wanted to have a public confirmation that they were under the direct rule of the Crown and that no other prince had authority over them. ${ }^{91}$ Frontier towns were particularly concerned to have the king's assurances that he would not give them away to another ruler. For example, Montagnac obtained letters from Philip VI in 1345 guaranteeing that the town would never be separated from the French Crown. ${ }^{92}$ This was a time of uncertainty and territorial change in Languedoc, as the French king was in competition with the kings of Majorca and Aragon for control of the region (indeed, the neighbouring city of Montpellier was sold to France by James III of Majorca). The transference of power from one ruler to another threatened the stability of urban liberties. At the very least, town leaders would have to seek the confirmation of their liberties from their new lord; at worst, these liberties could be abolished. Royal entries presented towns with a good opportunity to obtain a guarantee from the king that he would not give them away, which was especially important during periods of danger. When Charles viII entered Mâcon in June 1494, he swore 'to never alienate the county of Mâcon' and assured the civil council that the town 'was a jewel in his Crown'. ${ }^{93}$ Charles viII's entry into Mâcon took place as he marched to invade Italy, an

89 These poems can be found in Antoine Le Roux de Lincy, ed., Chants historiques et populaires du temps de Charles VII et de Louis XI (Paris, 1857), 116-45. See also: Claude Thiry, 'Les poèmes de langue Française relatifs aux sacs de Dinant et de Liège', in Liège et Bourgogne. Actes du colloque tenu à Liège les, 28, 29 et 30 octobre 1968 (Liège, 1972), 101-27.

9o AM Amiens BB 11, fol. 63r.

91 Chevalier, 'King's Council', 113.

92 AD Hérault, AC Montagnac 162 EDT 1.

93 Bazin, 'Rois de France à Mâcon', 63 . 
action that had reopened hostilities between France and the Holy Roman Empire. Lying on the river Saône, which marked the traditional border between France and the Empire - and in a region that Emperor Maximilian claimed was rightfully his - Mâcon could expect to receive the brunt of any imperial invasion of France. Hence, Mâcon's échevins introduced this clause into the oath at Charles viII's entry into order to safeguard their status as subjects of the king of France. Likewise, in 1472 La Rochelle's ruling council had Louis XI swear at his entry not to alienate the city from the Crown of France 'by exchange, appanage, marriage, or otherwise. ${ }^{94}$ As Louis's visit to La Rochelle marked its return to royal rule (Louis gave the city to his brother, Charles of France, in 1469), the consuls introduced this oath into the entry ceremony as a means to guarantee their status as a royal town. According to the text of oath, should Louis or any of his successors break the entry vow, the consuls could 'take or recognise as [their] lord such other lord as seemed good to them, without you [the consuls] or your said successors being designated, charged, or accused for the crime of lèse majesté, nor any other offence towards us or our successors to the Crown of France. ${ }^{95}$ This was a remarkable right for a king to grant; yet French monarchs were largely content to swear the oaths handed to them during a royal entry, which urban authorities devised (with no input from royal officials) to ensure the stability and maintenance of their rights.

Confrontations regarding the scope of urban liberties were rare because municipal councils tried to resolve any difficulties before the day of the entry. Civic delegations met the king in advance of an entry to obtain his assurance that he would confirm their privileges at the ceremony. In the days leading up to Louis XI's entry into Tournai in 1463, the municipal council sent its representatives to the king (then at Arras) 'to recommend the said town and the maintenance of the privileges'. The city council's deliberations record that Louis 'received and heard them well, saying that he would keep their privileges. ${ }^{96}$ Likewise, when Francis I entered Dijon in 1521, the échevins sent a delegation to the king (then at Villeneuve-sur-Yonne) to explain the oath-taking process. ${ }^{97}$ The pre-entry meeting allowed urban officials to work out any concerns the king had with the oath, thus avoiding a public confrontation on the day of the

\footnotetext{
94 Rivaud, Entrées princières, 115.

95 Rivad, Entrées princières, 115. In 1641, Louis XIII made the same promise to the Catalans in 1641, who recognised the French king's sovereignty during their revolt against Philip IV: Geoffrey Parker, Global Crisis: War, Climate Change \& Catastrophe in the Seventeenth Century (New Haven and London, 2013), 274-75.

96 La Grange, 'Entrées des souverains', 52.

97 Gouvenain, Inventaire sommaire, Dijon, ii. 7.
} 
entry. While Louis XI waited at Saint-Denis for the Parisians to finish preparing the city for his post-coronation entry in 1461 , an urban delegation came to explain the procedure for the oath taking ceremony at Notre-Dame. Although Louis had some concerns about the scope of the oath, these issues were resolved in advance of the entry and the event passed off without incident. ${ }^{98}$ It was in the municipal council's interest to speak to the king in advance of his entry, as any problems that were played out in public on the day would only undermine the municipal council's authority in front of the townspeople who gathered to watch the extramural greeting (including rival urban authorities, such as the cathedral canons or the royal officials of the bailliage).

Although the methods town councils employed to ensure that kings confirmed their liberties at the extramural greeting were largely successful, a rare instance of a public dispute about the nature of the oath occurred during Charles vII's inaugural entry into Paris in 1437. The king processed through the city's streets until he reached Notre-Dame, where the doors of the cathedral were closed on him. The bishop of Paris, Jacques du Chastelier, accompanied by the cathedral canons, met Charles outside Notre-Dame and explained that it was customary for French kings to take an oath to defend the Church at this point in the ceremony. The bishop then handed Charles the text of the oath monarchs were required to swear before they were admitted in to the cathedral. While the oath taking at Notre-Dame was a normal part of the Parisian post-coronation entry, Charles asked the bishop if it was customary, in response to which Chastelier assured him that it was. Despite receiving affirmations of the oath's validity from the bishop, the king called for the dauphin, his leading nobles and maitre-dès-requetes (as well as other influential members of his entourage) to consult with him. Once his advisors told Charles that his ancestors had taken the oath, he declared 'as my predecessors have sworn it, I swear it. ${ }^{99}$

98 Thomas Basin, Histoire des règnes de Charles VII et Louis XI, ed. J. Quicherat, 4 vols (Paris, 1855-59), ii. 15-18; Guenée and Lehoux, Entrées royales françaises, 93-95; Camille Couderc, 'L'entrée solennelle de Louis XI à Paris (31 août 1461)', Mémoires de la Société de l'histoire de Paris et de l'Ile de France 23 (1896), 139.

99 Guenée and Lehoux, Entrées royales françaises, 84-85. At the coronation entries of the duke of Brittany in Rennes, the gates of the town were closed until the duke had sworn an oath (which was similar to the oath French kings gave during their inaugural entries into Paris) before the bishop of Rennes: Godefroy, Cérémonial françois, i. 627; Michael Jones, 'The Rituals and Significance of Ducal Civic Entries in Late Medieval Brittany',Journal of Medieval History 29 (2003), 289-92. 


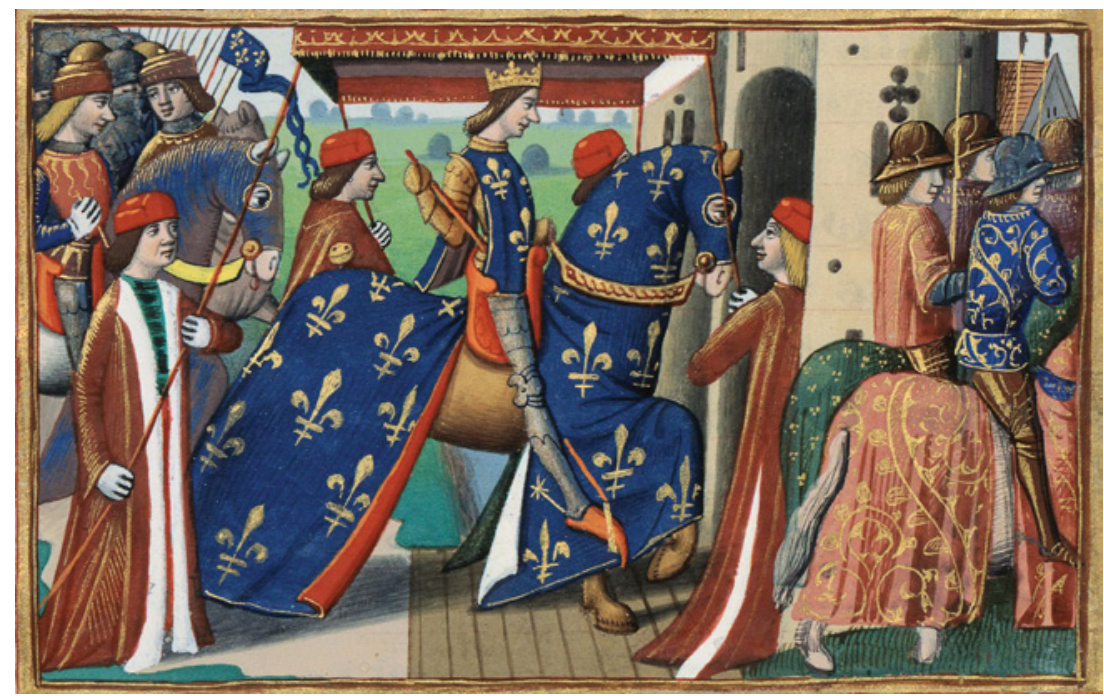

FI GURE 2 Charles VII's entry into Paris in 1437. Bibliothèque Nationale de France 5054, FOL. $93 \mathrm{~V}$.

Three principal reasons may account for the king's unusual actions, which threatened to jeopardise his recently renewed relationship with the rulers of Paris. First, Charles may have been genuinely unaware of the expectation to take the oath. As Charles had been exiled from Paris since 1419, he would have been unable to check the accounts of previous royal entries contained in the archives of Saint-Denis, as his ancestors had been accustomed to do. ${ }^{100}$ Furthermore, there is no evidence that Paris's secular or religious authorities sent a delegation to Charles in advance of his entry to explain the oath-taking ceremony (this was a serious oversight, which jeopardised the ceremony). The second explanation for Charles's behaviour may be that he had not participated in an inaugural entry into Paris. His father's post-coronation entry was in 1380, over two decades before his birth. In addition, he was unable to make the customary entry into the capital after his coronation at Reims in 1429 because Paris was then under Lancastrian control. The third possibility (and perhaps the most likely) is that Charles was aware of the customary oath taking but

100 For example, in 1389, Blanche, the dowager queen of France, went to Saint-Denis to consult the abbey's records for accounts of royal entries into Paris in preparation for the forthcoming entry of Isabella of Bavaria (Charles VII's mother) into the capital as queen of France: M. L. Bellaguet, ed., Chronique du religieux de Saint-Denys, contenant le règne de Charles VI, de 1380 à 1422, 6 vols (Paris, 1839-52), i. 611. 
deliberately provoked a confrontation with the city's religious authorities in order to show his displeasure towards them. Not only had the bishop of Paris and the cathedral chapter given their support to the Lancastrian monarchy, Notre-Dame was the venue for the French coronation of Henry VI in December 1431 - a ceremony that was designed to damage the legitimacy of Charles vil's 1429 coronation in Reims. As the oath taken outside Notre-Dame concerned clerical rights, by questioning its legitimacy Charles warned the cathedral authorities not to take their privileges for granted, as these rights were dependent on his good will. ${ }^{101}$ Nonetheless, Charles's decision to confront the Parisian clergy over the scope of the oath was exceptional and it did not reflect the standard practice of oath taking during entry ceremonies in later medieval and Renaissance France.

\section{Keys and Banners}

The confirmation of urban liberties was bound up with the presentation of city keys, which were customarily offered to the monarch during the harangue. Although Pierre Vaillancourt writes that the offering of keys 'was purely protocol and did not have any consequence', in fact the act was a fundamental part of the dialogue between Crown and town because it symbolised the town's submission to his rule. ${ }^{102}$ According to Abbeville's municipal deliberations, the

101 In an effort to avoid any further confrontations at the doors of Notre-Dame, the bishop of Paris took the novel step of joining the extramural municipal delegation for Louis XI's inaugural entry in 1461 so that he could explain the oath taking procedure to the king: Couderc, 'Entrée de Louis XI à Paris', 129.

102 Vaillancourt, Entrées solennelles, Charles $I X$, 16. France was a large and diverse kingdom and there was a regional character to this act of submission. Whereas northern towns only handed over their keys to the king, many southern towns also offered a flag. For example, the leaders of both Toulouse and Montpellier presented Louis XI with banners at his entries: AM Toulouse AA 3/277; Marcelle Bonnafous, 'Toulouse et Louis XI', Annales du Midi 39-40 (1927-28), 16; J. Calmette, 'L'iconographie toulousaine de Louis XI', Annales du Midi 65 (1954), 280; Oudot de Dainville, Archives de la ville de Montpellier: Inventaires et documents. VII: inventaire de Joffre, archives du greffe et de la maison consulaire (Montpellier, 1939), 65. Likewise, Rodez's municipal council sent a delegation to Albi in 1443 to take an oath of loyalty to the dauphin Louis and offer him their keys. In response, the dauphin instructed Rodez's consuls to place his banner on the town gates as a marker of his legitimacy to rule and completed the ceremonies of integration on 18 February 1445 when he made his inaugural entry into Rodez: Henri Affre, Inventaire sommaire des archives communales antérieures à 179o. Ville de Rodez (Rodez, 1878), 51; AD Tarn 4 EDT AA 4, fol. 143r. In 1438, the dauphin, Louis, entered Albi with his 
échevins handed over their keys to Charles VIII in 1493 as a 'sign of obedience and recognition that he was their sovereign king and natural lord.' ${ }^{103}$ Yet the offering of keys and flags was more than a simple recognition of royal power. In 1495, the citizens of Lucca offered their keys to Charles VIII 'signifying the total submission of the town to his obedience... and that it would please him to be their protector'. ${ }^{104}$ By accepting their keys, the king was bound to act as the city's guardian and uphold their privileges.

The French monarch confirmed urban privileges in return for this public acknowledgement of his sovereignty. As soon as Louis XI took possession of the flag and keys offered to him at Toulouse, he approached the gate of entry to confirm the city's liberties. A missal was opened for the king at the Te igitur (a passage strongly associated with the offering of gifts and kingship). The capitoul Nicholas d'Auterive explained to Louis that his predecessors had always confirmed the rights of the town at this point in the ceremony. ${ }^{105}$ Urban administrations regularly appealed to past precedent. When Louis XI entered Tournai, its échevins also advised the king that his ancestors had maintained the city's liberties during their entries. ${ }^{106}$ The invocation of past precedent by municipal councils formed a part of their strategy to ensure that urban liberties were confirmed undiminished. It was a shrewd way to influence royal behaviour, as a king who failed to respect local customs could be accused of tyranny.

Urban administrations used the key presentation to emphasise the extent of their devotion to the Crown, in return for which they expected the king to act in their favour. When the échevins Charles Décrivieux and Guillaume Delaporte presented Mâcon's keys to Louis XII in 1512, they informed the king that they were at his complete disposal ('cors et biens'). ${ }^{107}$ Likewise, when Charles IX entered Sens in 1564, the échevins offered 'in all humility, obedience and subjection, not only these keys to your old town of Sens, but those to our goods which are all yours'.108 The use of courteous phrases by town councils underscored their readiness to serve the king, which was symbolised by the

standard carried before him, and had the keys presented to him: AD Tarn 4 EDT CC 188,

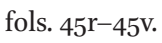

103 Ledieu, 'Charles VIII à Abbeville', 6.

104 Vigne, Voyage de Naples, 197.

105 AM Toulouse AA $3 / 277$.

106 La Grange, 'Entrées des souverains', 48.

107 Bazin, 'Rois de France à Mâcon', 69. The offering of 'cors et biens' symbolised the town's value for the monarchy and this phrase (or variants of it) was used regularly during entries. See, for example: Thomas Mermet, Ancienne chronique de Vienne (Vienne, 1845), 168.

108 Vaillancourt, Entrées solennelles, Charles IX, 77. 
offering of keys. By offering their goods to the king, the urban elite expected the king to respond in kind and accord grants that increased their prosperity (which also benefitted the king because it enabled the townspeople to offer high-quality gifts to the monarch). Municipal administrations drew attention to the extent to which they relied on the monarch's patronage by handing over the actual keys to their gates rather than ceremonial copies. ${ }^{109}$ When Louis XI entered Lyon on 23 March 1476, the échevins gave him the keys to all of the city gates to keep for the duration of his visit. ${ }^{110}$ By giving their keys to the monarch, town councils entrusted him with their security. Hence, the offering of city keys was both a mark of loyalty to the Crown and an acknowledgement of the king's power to protect his subjects.

As keys were a symbol of sovereignty, they were only offered to the ruler or his representatives. However, municipal governments could seek royal permission to offer their keys to particularly important visitors because it allowed them to seek their favour. After marrying Charlotte of Savoy in 1451, the dauphin, Louis, prepared to enter Bourg-en-Bresse, which was then under Savoyard rule. In preparation for this entry, Bourg's consuls wrote to the duke of Savoy asking if they should present their keys to the dauphin. The opportunity to grant Louis the honour of a key presentation stood to benefit the town council because it could use the gesture to ingratiate itself with the future ruler of France (and possibly Savoy). The duke permitted Bourg's leaders to offer their keys to the dauphin, as Louis had instructed the towns of Dauphiné to present the duke with their keys when he toured the region earlier that year. ${ }^{111}$ While Bourg-enBresse lay outside the kingdom of France, this francophone town was dependent on commerce with France for its prosperity. As such, the opportunity to win the dauphin's favour stood to potentially benefit Bourg for years to come. While kings instructed towns to offer their keys to visiting dignitaries in order

109 Other urban authorities could hand over their keys to the king at an entry ceremony. When Louis XII entered Compiègne in 1498, he received the keys held by the captain during the extramural greeting: Ам Compiègne в в 13, fols. 150r-151r. Louis XI received those of the lieutenant, captain and town council of Beauvais at his entry in 1474: BM Beauvais, Coll. Bucquet, vol 57, p. 3 .

110 Guenée and Lehoux, Entrées royales françaises, 218-19. When Eleanor of Austria entered Troyes in 1533, the échevins took the city's iron keys and had them bleached in order to make them look more appealing for the presentation: Babeau, Rois de France à Troyes, 40.

111 J. Brossard, 'Éntree à Bourg du duc Louis en 1451', Annales de la Société d'Émulation, agriculture, lettres et arts de l'Ain 14 (1881), 217, 221. As king, Louis XI also granted his fatherin-law the honour of the key presentation during the entries the duke of Savoy made into French towns: Aм Amiens в в 9, fols. 124v-125r, 154r; Alcuis Ledieu, Budget communal d'Abbeville en 1464 et 1465 (Paris, 1904), 20-21. 
to support their diplomatic efforts, urban leaders also used this gesture to further their commercial efforts. Louis XI instructed the Norman towns to offer their keys to Richard Neville, earl of Warwick, when he toured the duchy in 1467. Louis was trying to devise an alliance with the earl (who was then the most powerful man in England) and these gestures of distinction formed a part of his strategy to honour the earl. ${ }^{112}$ The staging of these entries also worked to Rouen's advantage because with the end of the Hundred Years' War the city was in a good geographical position to profit from trade with England. From the perspective of Rouen's échevins, gaining the support of the earl of Warwick would be a good way to promote the city's position with a pro-French ruling faction in England and to encourage a privileged position for its merchants in cross-Channel trade. As Rouen's leaders also feared an English invasion throughout the later fifteenth century, obtaining the good favour of the earl of Warwick had the potential to reduce the threat to the city's security from the seaward frontier.113

Whereas Richard Neville received Rouen's keys as a token of honour, fifty years earlier, during the English conquest of Normandy in 1417-19, Norman towns, including Rouen, had offered their keys to Henry v in acknowledgment of his rulership. As keys were normally bound up with concerns of sovereignty, municipal administrations sent them to the ruler in advance of an entry as an acknowledgement of his right to rule. In return for supporting the ruler's legitimacy to rule, French towns and cities were able to obtain an extension of their privileges from the new leading power in their region. The pre-entry submission of keys was especially common when the control of a region passed from one lord to another. On the day that Louis XI repurchased the Somme towns from Philip the Good in 1463, he sent royal officers to Abbeville to receive its keys. This gesture symbolised the establishment of Louis's rule over the town, which was formalised at his inaugural entry later that year. ${ }^{114}$ Beyond the symbolic value of this gesture, municipal councils used the submission of keys as the pretext for negotiating new privileges in advance of a ceremonial entry.

112 Charles de Beaurepaire, 'Notes sur six voyages de Louis XI à Rouen', Académie imperiale des sciences, belles-lettres et arts de Rouen (1856-57), 310; Basin, Histoire de Louis XI, ii. 178; Vaesen and Charavay, Lettres de Louis XI, iv. 37-38.

113 See: Neil Murphy and Graeme Small, 'Town and Crown in Late-Fifteenth Century France: Rouen after the Rédution, c.1449-c.1492', in Anne Curry and Véronique Gazeau, eds., La guerre en Normandie (XI ${ }^{e}-X V^{e}$ siècle) (Rennes, forthcoming).

114 A. Ledieu, Ville d'Abbeville. Inventaire sommaire des archives municipales antérieures à 1790 (Abbeville, 1902), 107; Robert Richard, 'Louis XI et l'échevinage d'Abbeville', Mémoires de la Société d'émulation historique et littéraire d'Abbeville 27 (1960), 15-16. 
When Charles VII and Joan of Arc fought their way across Anglo-Burgundian Champagne in 1429 to have the Valois monarch crowned at Reims, numerous towns offered their keys to the king as a sign of submission. ${ }^{115}$ In return for this recognition of his rule, Charles granted these urban administrations extensive new liberties. Reims used the rendering of its keys as a pretext to offer its petitions to the king, who was only permitted to enter the city after he had granted the townspeople's requests. As the principal objective of Charles's 1429 progress was to be crowned at Reims, the municipal leaders capitalised on the city's wider importance to Valois king's cause in order to obtain lucrative new rights and liberties. ${ }^{116}$ Likewise, the rulers of Troyes were able to obtain a number of important new rights (including garrison exemption) from Charles VII in 1429 before they permitted him to enter the city. ${ }^{117}$ As the English held Brie and the Burgundians dominated the Seine upstream, Troyes was of great strategic value to Charles VII, who was prepared to concede a range of significant economic and political rights to secure its loyalty. ${ }^{118}$ Before Charles entered Compiègne with Joan of Arc on 18 August 1429, he pardoned the inhabitants and accorded the town council the right to levy a wine tax. ${ }^{119}$ In return for these grants, Compiègne's échevins expelled the Burgundian garrison and gave their support to the Valois monarch. In sum, the new rights Charles vi granted to the towns of Champagne during the key presentations helped to secure his rule in the region; indeed, Troyes and Compiègne were instrumental in defending Champagne against Anglo-Burgundian attacks during the $1430 s .{ }^{120}$

115 BNF Collection Français 11672, fols. 237v-238r; Douët-d'Arcq, Chronique de Monstrelet, iv. 335-40, 352-53; Georges Clause and Jean-Pierre Ravaux, Histoire de Châlons-sur-Marne (Roanne-le Coteau, 1983),106; Édouard de Barthélemy, Histoire de Chalons-sur-Marne et de ses institutions (Chalons, 1854), 182-83; Henri Martin and Paul Jacob, Histoire de Soissons, 2 vols (Soissons, 1837), i. 385 .

116 Godefroy, Cérémonial françois, i. 166.

117 Alphonse Roserot, ed., 'Le plus ancien registre des délibérations du conseil de ville de Troyes (1429-1433), in Collection de documents inédits du conseil de la ville de Troyes, 3 vols (Troyes, 1886), iii. 178-79; Charles Petit-Dutaillis, The French Communes in the Middle Ages, trans. Joan Vickers (Oxford, 1978), 141. Laurière, Ordonnances rois de France, xiii. 142.

118 Léonard Dauphant, Le royaume des quatre rivières: l'espace politique français, 1380-1515 (Seyssel, 2012), 90-91.

119 AM Compiègne CC 13, fols. 245r, 249v; H. de Lépinois, 'Notes extraites des archives communales de Compiègne', Bibliotheque de l'Ecole des Chartes 4 (1863), 484; J. Randier, 'Le gouvernement de la "bonne ville" de Compiègne et ses hommes au temps de la reconstruction (1468-1500)', Bulletin de la société historique de Compiègne 38 (2002), 81-82.

120 M. T. Boutiot, Guerre des Anglais 1429-1435: un chapitre de l'histoire de Troyes (Paris and Troyes, 1861); Louis Carolus-Barré, 'Compiègne et la guerre, 1414-30', in La 'France 
During Charles viI's re-conquest of Normandy in 1449-50, the duchy's municipal leaders employed a strategy similar to that used by the échevins of Champagne in the late 1420s. As part of the negotiations that preceded Charles vir's entry into Rouen, the échevins obtained the monarch's confirmation of 'all their rights, franchises and liberties', in return for which they offered him the keys to the city. In advance of this meeting with the king, the Rouennais recruited the services of Jean, count of Dunois, who held great influence with the king. Dunois spoke on the city's behalf to the king during the pre-entry negotiations, persuading Charles to treat the townspeople favourably. ${ }^{121}$ Even without Dunois' support, the échevins were able to negotiate with the Valois monarch from a position of strength. Although large parts of Normandy had returned to Valois rule in 1449, Rouen was well defended by a large Lancastrian garrison under the able command of John Talbot. Without the support of Rouen's leaders, Charles faced a long and costly siege, with no guarantee of success. Although Henry vi's French policy was chaotic, reinforcements were then being gathered in England to reinforce Talbot's troops in Rouen. ${ }^{122}$ In return for confirming their rights, the municipal council opened the gates to Charles's forces and overthrew the English garrison. Rouen's leaders used the same tried and tested strategy seventeen years later when Louis XI retook control of Normandy from his brother, Charles of France. The échevins sent a delegation to the king at Pont-de-l'Arche to seek his pardon and obtain the confirmation of their liberties 'and numerous other requests'. After obtaining these demands, the citizens opened the city's gates to Louis's soldiers and expelled those people who had opposed the monarch. Although Louis appointed royal officers and executed some of those who had taken his brother's side in the war, he also ratified the city council's rights and liberties. ${ }^{123}$ As Rouen's experiences throughout the wars of the fifteenth century illustrate,

anglaise" au Moyen Age, colloque des historiens médiévistes français et britanniques. Actes du n11e Congrès national des sociétés savantes (Poitiers, 1986), 386-87.

121 Beaucourt, Chronique Mathieu d'Escouchy, i. 222, 232; J. J. de Smet, ed., 'Chronique des Pays-Bas, de France, d'Angleterre et de Tournai', in Recueil de Chroniques de Flandre (Brussels, 1856), iii. 440; Henri Courteault and Léonce Celier, eds., Les chroniques du roi Charles VII par Gilles Le Bouvier dit le Héraut Berry (Paris, 1979), ii. 319.

122 C. T. Allmand, 'The Lancastrian Land Settlement in Normandy, 1417-50', Economic History Review 21 (1968), 478-79; Ralph A. Griffiths, The Reign of Henry VI: The Exercise of Royal Authority, 1422-1461 (London, 1981), 514-15.

123 A. Heron, ed., Deux chroniques de Rouen (Rouen, 1900), 101; Mélanges historiques, choix de documents, 5 vols (Paris, 1873-86), ii. 419; Chronique Scandaleuse, i. 187; Basin, Histoire de Louis XI, i. 151-52. 
a royal visit was a proven mechanism for towns to obtain the security of their liberties even when they had opposed the Crown.

Pre-entry grants principally occurred during periods of internal conflict, when the Crown was weak and in need of support from urban governments. Between December 1419 and June 1420, Charles VII (then dauphin) made substantial concessions to the towns he entered during his tour of Languedoc. ${ }^{124}$ Charles fled Paris in 1419 as a result of his suspected role in the murder of John the Fearless, following which his father, Charles vi, and the principal political institutions of the kingdom (including the Parlement of Paris), under pressure from Henry v, disinherited him from the succession to the throne of France. As a result of these difficulties, Charles used the granting of new rights as a means to encourage southern communities to recognise the legitimacy of his rule. The dauphin made these grants after receiving entries that included royal honours such as the canopy, which endorsed his claim to be the regent of the kingdom and heir to his father's throne. ${ }^{25}$ Bernard Chevalier correctly identified Charles viI's reign as the moment when an entente cordiale developed between the Crown and the kingdom's urban elites. In return for receiving municipal support, Charles conferred substantial privileges on the bonnes villes. ${ }^{126}$ Towns were administrative, military and commercial centres and their possession was a key feature of warfare during the fifteenth century. Chevalier saw the 1440 s as the crucial decade in the formation of this entente cordiale, claiming that close links between town and Crown developed during the princely revolt of the Praguerie. ${ }^{127}$ In fact, Charles granted the bulk of new urban rights and liberties before the capitulation of Paris in 1436, when his position was weak and he needed urban support. Although Charles confirmed the privileges of towns that submitted to him after 1436, when his rule

124 Dauphant, Royaume, 280.

125 Alicot, Thalamus parvus, 468-69. For the representation of ceremonial entries in this document, see: Vincent Challet, 'Entrées dans la ville: genèse et développement d'un rite urbain (Montpellier, XIV ${ }^{\mathrm{e}}-\mathrm{XV}$ e siècle)', Revue historique 670 (2014), 267-93.

126 Bernard Chevalier, Les bonnes villes de France du XIV eu XVIe siècle (Paris, 1982), 101-6; J. Russell Major, From Renaissance Monarchy to Absolute Monarchy: French Kings, Nobles, \& Estates (Baltimore and London, 1994), 44.

127 Bernard Chevalier, 'Un tournant du règne de Charles VII. Le ralliement des bonnes villes à la monarchie pendant la Praguerie', in idem, Les bonnes villes, l'État et la société dans la France de la fin du XV siècle (Orleans, 1995), 155-67; idem, 'L'état et les bonnes villes en Fance au temps de leur accord parfait (1450-1550)', in Neithard Bulst and J.-P. Genet, eds., La ville, la bourgeoisie et la genèse de l'état moderne (XII $-X V I I I^{e}$ siècles) (Paris, 1988), 72. 
was more secure, he did not grant them additional privileges in advance of his entries (see, for example, his entry into Rouen discussed above). ${ }^{128}$

To return to the keys, the king normally entrusted them to one of his officials who retained them for the duration of a royal visit. When Charles viI entered Rouen in 1449, for example, he passed its keys to Pierre de Brézé, whom he had just appointed captain of the city. ${ }^{129}$ With the growth in the number of the French king's household troops during the second half of the fifteenth century, city keys came to be handed to the king's chief guards. As soon as Francis I received the keys to Toulouse in 1533, he passed them to the captain of his Garde Écossaise. ${ }^{130}$ Monarchs returned the keys to town councils when they wanted to show public trust in civic leaders. This gesture was particularly common at royal entries into frontier cities that had resisted foreign domination. When Tournai's municipal council offered its keys to Louis XI in 1463 , he immediately returned them to the échevins saying they had always guarded it [the city] well and continued to do so'.131 By the mid-fifteenth century, Tournai was a French enclave deep within the Burgundian lands. It was a frontier city par excellence and Louis XI was the first French monarch to visit Tournai in eighty years. Although the city's leaders often felt distant from the Crown, they remained loyal to the Valois monarchy during the Hundred Years' War and the Franco-Burgundian conflicts, resisting both English and Burgundian domination. ${ }^{132}$ Louis thanked Tournai's government for its loyalty to the Valois monarchy by returning its keys at the entry. Similar circumstances led Francis I to hand back the keys to Dijon's mayor when he entered the city in 1521. ${ }^{133}$ Dijon's location on the eastern frontier of the kingdom placed its population at the centre of the Valois-Hapsburg wars. The city had successfully resisted Charles v's armies during the siege of 1513 and Francis articulated his trust in the capability of the municipal administration to protect the frontier of his kingdom by returning the keys. ${ }^{134}$ As we shall see in chapter two, the

128 Hippolyte Dansin, Histoire du gouvernement de la France pendant le règne de Charles VII (Geneva, 1858), 318-20.

129 Courteault and Celier, Chroniques du roi Charles VII, 326.

130 AM Toulouse AA 5/97.

131 La Grange, 'Entrées de souverains', 53.

132 Graeme Small, 'Centre and Periphery in Late Medieval France: Tournai, 1384-1477', in Christopher Allmand, ed., War, Government and Power in Late Medieval France (Liverpool, 2000), 145-74.

133 Gouvenain, Inventaire sommaire, Dijon, i. 54.

134 Likewise, when the dauphin entered Beauvais in 1544, he returned the keys to the mayor asking him 'to keep the town loyally for the king, saying he knew well that [it] would be done': вм Beauvais, Coll. Bucquet, vol. 57, p. 601. 
king's confidence in the governments of frontier towns such Dijon and Tournai led him to grant them significant liberties. In order words, having the king return the keys at an entry was a strong indication to urban administrations that he was well disposed to receive their petitions for substantial new rights.

Between the expulsion of the English from France in 1453 and the onset of the religious wars, the kingdom's areas of persistent conflict were largely confined to its frontier regions. The opening of civil war in the 1560 os led to a return to the destabilising conditions of the Hundred Years' War and large swathes of the kingdom became zones of incessant conflict. As a result of internal warfare during the later sixteenth century, towns and cities across the kingdom found themselves on a frontier once again. This political instability was reflected in the form of key presentations during this period. When Philippe de Volure, governor of Angoumois, entered Angoulême on 12 November 1573 as Charles IX's representative, the Catholic mayor, Mathurin Martin, offered him the keys to the town gates. The civic records note that the governor 'did not want to receive them, saying that they were in the hands of a good and loyal servant of the king, who had done his duty well by stopping the enemy surprising the town' ${ }^{\prime 35}$ While Angoulême's location in the centre-west of the kingdom meant that it was far from the main areas of conflict in the century between 1460 and 1560 , the growth of Protestantism in the region placed the town at the heart of the religious wars of the later sixteenth century. The governor's return of the keys to Angoulême's leaders formed part of the Crown's efforts to maintain control of this former bastion of Protestantism in the wake of the edict Charles IX had issued at Boulogne in July that year, which stripped Huguenots of many of the rights they had been granted by the Peace of Saint-Germain-enLaye (August 1570). ${ }^{136}$

Town councils devised distinctive key presentations in order to to draw the king's attention to this important act. ${ }^{137}$ Tournai's keys were brought to Louis XI in a wooden castle that was attached to a horse's saddle. The city's incorporation of the key presentation into the theatricality of event pleased the king, who was 'very happy' with the échevins' efforts. ${ }^{138}$ For Henry II's entry

135 J.-F. Eusèbe Castaigne, 'Entrées solennelles dans la ville d'Angoulême depuis François Ier jusqu'à Louis XIV', Buletin de la Société archéologique et historique de la Charante 1 (2nd series) (1856), 317-18.

136 A.-F. Lièvre, Angoulême: histoire, institutions \& monuments (Angoulême, 1885), 39-44.

137 See, for example: M. A. Matton and M. V. Dessein, Inventaire sommaire des archives communales antérieures à 1790. Ville de Laon (Laon, 1885), 74; Ledieu, 'Éléonore d'Autriche à Abbeville', 58 .

138 La Grange, 'Entrées de souverains', 42. 
into Reims in 1547, the échevins had a 'beautiful virgin richly dressed, decorated with jewellery and representing the town of Reims' offer the city keys to the king outside the gate of entry. The playful manner of the key presentation encouraged Henry II to respond to the échevins' gesture in an unusually direct way. According to one eyewitness, Henry 'showed great pleasure at this thing', following which he spoke to the woman directly and then kissed her. ${ }^{139}$ By the mid-sixteenth century, contemporary expectations that kings should remain remote and emotionless during the public entry meant that this type of direct communication was unusual. By skilfully devising a distinctive key presentation, Reims' échevins persuaded the king to engage directly with a woman who symbolised the identity of the town. When Henry III entered Reims in 1575, the town council once again offered its keys to the king from the hands of a welldressed and beautiful young woman, who was lowered from a building in a chariot. ${ }^{140}$ By recycling the form of Henry II's key presentation, Reims' échevins used a proven method to emphasise the extent of their attachment to the Valois monarchy, and to encourage the king to transcend contemporary standards of behaviour. As French monarchs became increasingly remote in the public entry from the mid-sixteenth century, town councils devised increasingly inventive ways to persuade him to interact with their representatives.

Young women participated in key presentations across France during the sixteenth century. When Charles IX entered Nîmes on 12 December 1564, two young townswomen - who were noted for their beauty - offered him the keys to the city. ${ }^{141}$ We find the presence of women in the extramural greeting from the mid-fourteenth century, when they greeted the king and occasionally carried a canopy above him (such as the 'beautiful and noble young women' who raised a pallium over Charles vi at Lyon in 1389). ${ }^{142}$ These women symbolised civic identity: when Charles VII entered Rouen in 1449, he was introduced to 'a woman who signified the town', while Francis I was greeted at Langres in

139 Kraft, Henri II dans la ville de Reims, 279-80.

140 Godefroy, Cérémonial françois, ii. 322.

141 Vaillancourt, Entrées solennelles, Charles IX, 16; M. Menard, Histoire civile, ecclésiastique et littéraire de la ville de Nismes avec les preuves, 7 vols (Paris, 1744-58), iv. 401. See also for Henry II's entry into Châlons in 1552: Barthélemy, Histoire de Châlons-sur-Marne, 201.

142 Guenée and Lehoux, Entrées royales françaises, 143. Occasionally, these women offered the king gifts. Upon entering Dijon in 1494 Charles viII was greeted by 'a beautiful young woman, who gave him a golden heart': M. Rossignol, 'Histoire de Bourgogne: Charles VIII', Mémoires de l'Académie des sciences, arts et belles-lettres de Dijon 9 (1861), 135. This custom was also used at entries in the Low Countries: Jesse Hurlbut, 'Symbols for Authority: Inaugural Ceremonies for Charles the Bold', in T.-H. Borchert et al., eds., Staging the Court of Burgundy (Turnhout, 2013), 107. 
1521 by 'a young woman representing Langres seated on a chair decorated with many fine colours' who 'spoke to the king with greatsubmission and reverence.'.143 When Louis XI entered Lyon in 1462, the municipal council attached their keys to a large statue of a lion (the city's symbol) outside the gate of entry. In order to accentuate civic identity, Lyon's consuls had two young women stand on either side of the statue. ${ }^{144}$ Moreover, the townswomen who presented the city keys to the king linked their families to the monarch. Eleanor of Austria received Abbeville's keys from the daughter of Nicholas de Gagny, who was one of the town's leading men. ${ }^{145}$ Such strategies formed an additional means for urban elites to develop personal links with the king and promote their interests with him. Furthermore, as the young women who offered the keys to the monarch were often dressed as angels, this act linked the earthly city with the Heavenly Jerusalem. ${ }^{146}$ For Louis XII's entry into Rouen in 1508 , the municipal council constructed a stage just outside the gate of entry, where two actors dressed as angels descended from the top of the gate - as if from heaven - and offered the city's keys to the king. ${ }^{147}$ Hence, the key presentation was transformed into a sacred gesture, drawing upon biblical accounts detailing the offering of the keys of heaven and identifying Rouen as the New Jerusalem. This gesture reinforced the sacred nature of the king's confirmation urban liberties, which took place at this point in the ceremony.

Finally, it was crucial for a town's well being that the king or his representatives accepted the keys. When the monarch refused to accept the keys of a rebellious town, its population was left open to punitive punishment. In other words, a refusal to accept urban keys represented the Crown's refusal to negotiate. When a rebellion broke out in Bordeaux in 1548, Henry II sent

143 Guenée and Lehoux, Entrées royales françaises, 162; E. Jullien de La Boullaye, 'Entrées et séjours de François Ier à Langres', Bulletin de la Société historique et archéologique de Langres 1 (1872), 74-75. See also: Anne-Marie Lecoq, François Ier imaginaire. Symbolique et politique à l'aube de la Renaissance française (Paris, 1987), 369-74.

144 J.-R. Boulieu, 'Louis XI à Lyon', Revue d'histoire de Lyon 2 (1903), 400; Albert Champdor, Les rois de France à Lyon (Lyon, 1986), 18. For female actors and the presentation of keys to kings see also: Godefroy, Cérémonial françois, i. 185-87; Ruben, Registres consulaires, Limoges, ii. 119 .

145 Ledieu, 'Élénore d'Autriche à Abbeville', 58.

146 For royal entries and the Heavenly Jerusalem see: Ernst H. Kantorowicz, 'The "King's Advent" and the Enigmatic Panels in the Doors of Santa Sabina', in idem, Selected Studies (Locust Valley, 1965), 37-75; Kipling, Enter the King, especially chapters 1 and 2. For the New Jerusalem, see also: Keith D. Lilley, City and Cosmos: The Medieval World in Urban Form (London, 2009), 15-73.

147 Le Verdier, Entrée de Louis XII à Rouen, 5. 
the constable, Anne de Montmorency, to suppress the rising. In an attempt to avoid retribution, Bordeaux's jurades sent a delegation to offer the city's keys to the constable. However, Montmorency refused to accept them. ${ }^{148}$ Bordeaux was then stripped of its privileges and almost one hundred and fifty bourgeois (including members of the ruling council) were executed. By rejecting the key presentation, the constable refused to participate in a ritual that would have bound him to spare the town from serious punishment. When Montpellier revolted against the governor of Languedoc, Louis of Anjou, in 1378 over the imposition of a heavy tax, the duke laid siege to the city. When it became clear that Montpellier could not hold out against the royal army, the consuls sent a delegation dressed in penitential clothing to express their contrition to Charles. The consuls hoped that by engaging the governor in this ceremony they would oblige him to forgo sacking the city. However, Charles refused to participate in the city's ceremonial submission; instead, he ordered the execution of six hundred of the city's wealthiest residents by burning, drowning and hanging (though this sentence was later commuted to a large fine). ${ }^{149}$ As these examples illustrate, the offering of municipal keys was much more than an insignificant token of a town's submission to the king. It was a crucial tool in the negotiations that took place between town and Crown over the issue of urban rights.

\section{Changes to the Extramural Greeting}

While Jean-Pierre Leguay found that the extramural element of the entries of the dukes of Brittany was 'an unchanging ritual', the adjustments made to the greetings staged for the Valois monarchs altered the nature of town-Crown relations. ${ }^{150}$ In particular, the changes made to the form of the extramural reception in the mid-sixteenth century created a distance between the king and his townspeople. As a result of these alterations, the confirmation of urban

\footnotetext{
148 Tatiana Baranova, 'Le discours anti-tyrannique dans la France d'Henri II: un des sens multiples du Pasquille sur la rébellion de Bordeaux et la conduite du connétable', Histoire, économie, société 21 (2002), 484-85; S.-C. Gigon, La révolte de la gabelle en Guyenne (Paris, 1906), 163.

149 Eustache Deschamps, Oevures complètes de Eustache Deschamps, ed. Marquis de Queux de Saint-Hilaire, 10 vols (Paris, 1878-1903), iii. 67-68; Françoise Autrand, Charles VI: la folie du roi (Paris, 1986), 828.

$15^{0}$ Jean-Pierre Leguay, 'Un aspect de la sociabilité urbaine: les fêtes dans la rue en Bretagne ducale aux XIV et XV siècles', Mémoire de la Société d'histoire et d'archéologie de Bretagne 71 (1994), 28.
} 
liberties lost its central place in the extramural greeting, which profoundly altered the nature of the ceremony. These developments were a result of the move by French towns to have their privileges confirmed at court at the beginning of a new monarch's reign, rather than waiting for an inaugural entry. While the origins of this trend have traditionally been dated to the reign of Louis XI (1461-1483), we can find examples of this process from the 1430 os. ${ }^{111}$ The scale of Charles vir's conquests from 1429 meant that the king was not always present at a town's surrender. While Bernard, lord of Châteauvillain, restored Langres to Valois rule in 1433, Charles's preoccupations in other parts of the kingdom caused him to postpone his inaugural entry into the town. As Charles had still not entered Langres by 1437, the town council decided to send a delegation to the monarch (who was based at Bourges) to have its privileges confirmed and registered in the Chambre de Comptes. From this moment, the rulers of Langres sent a delegation to court at the beginning of each new monarch's reign to have their liberties confirmed, rather than waiting for the inaugural entry. ${ }^{152}$ While they may not have realised it, Langres' échevins were at the forefront of a practice which became the norm by the mid-sixteenth century.

The trend to have liberties confirmed at court was also a consequence of the French monarchy's success in expanding its territories and imposing its power more firmly across the kingdom. Charles VII confirmed Rouen's liberties on 19 July 1449 , three months before the city returned to his rule. ${ }^{153}$ The pre-entry confirmation of Rouen's liberties allowed the king to reassure the citizens that a return to Valois rule would not lead to the abolition of their privileges as a punishment for supporting the Lancastrian monarchy. As we saw earlier, this tactic was effective and Rouen's citizens overthrew the English garrison and opened their gates to Charles viı's soldiers. Accordingly, when Charles made his inaugural entry as king into the city on 10 November 1449, the confirmation of municipal liberties did not feature in the extramural greeting. ${ }^{154}$ As well as restoring Valois rule to territories such as Normandy, French monarchs also

\footnotetext{
151 Bryant, King and the City, 42; Davis, The Gift, 156.

$15^{2}$ For example, Langres had its liberties confirmed by Francis I at Paris in February 1515, and by Louis XII on 12 July 1498: Julien de la Boullaye, Inventaire sommaire des archives communales de Langres antérieures à 1790 (Troyes, 1882), 103, 172, 355. For the charter of liberties confirmed by French monarchs at Langres, see: S. Migneret, Précis de l'histoire de Langres (Langres, 1835), 345-55.

153 AD Seine-Maritime, Am Rouen A 7, fol. 52r.

154 G. du Fresne de Beaucourt, 'Charles VII à Rouen en 1417, 1418 et en 1449', Bulletin de la Société de l'histoire de Normandie 3 (1880-83), 336-45; Guenée and Lehoux, Entrées royales françaises, $160-62$.
} 
acquired new lands. Louis XI absorbed the independent county of Provence into the French kingdom in 1481 following the death of its last Angevin ruler. As Provence lay far from the centres of Valois power in the north, the French king rarely visited the region. Consequently, Provençal towns sent delegations to court soon after the ascension of a new monarch to give their oath of loyalty to the king and receive the confirmation of their privileges. Although Arles' rulers declared in 1481 that they would only take an oath to the French king after either he or one of his representatives visited the town and confirmed its privileges, the consequences of this stance led the town council to modify its position. ${ }^{155}$ As Louis XI, Charles VIII, Louis XII and Henry II did not visit Arles, it was imperative that the town had its liberties confirmed at court, rather than wait in expectation for a royal entry. Although Francis I and Charles IX made entries into Arles in the early years of their reign, the town council had already obtained the confirmation of its privileges in advance of these visits. ${ }^{156}$ The changing political conditions in France, especially the expansion of the monarchical state, meant some towns had to wait for years to have their liberties confirmed at an inaugural entry; indeed, as we saw at Arles, the inaugural entry might never take place. Hence, urban governments, particularly those on the frontiers, took the initiative to have their rights secured at the very beginning of the king's reign. In contrast to conditions on the periphery of the kingdom, towns and cities lying close to the centres of royal power were able to have their liberties confirmed by the monarch at one of his many visits. For example, when Louis XI visited Tours for the first time as king (soon after his coronation in 1461), the town was able to obtain the confirmation of its rights and franchises. ${ }^{157}$ Similarly, towns in the north-east of the kingdom did not need to send delegations to court to have their liberties ratified because French monarchs customarily made ceremonial entries into these towns as they progressed from Reims to Paris after the coronation. When Henry iI swore to forgo making his customary post-coronation entries into northern towns until he had campaigned in Italy, Amiens was forced to take the novel step of sending a delegation to court to have its liberties confirmed. However, having to travel to court to obtain the confirmation of urban liberties was both time-consuming and expensive. While Amiens' delegation departed for court in November 1547,

\footnotetext{
155 Aм Arles B B 5, fol. 271r.

156 Aм Arles в B 5, fol. 324r; Philippe Rigaud, 'Arles de 1481 à 1588', in Jean-Maurice Rouquette, ed., Arles: histoire, territoires, cultures (Paris, 2008), 479. Other Provençal towns also had their privileges confirmed at court. See: AM Aix-en-Provence AA 9, n. 13, AA 16, fols. 145r, 154r, 162r.

157 AM Tours AA 1. See also those of Francis I: AA 2.
} 
they were unable to obtain the ratification of their rights until February 1548. Furthermore, Amiens had to provide gifts to the procureur général of the conseil prive to have their privileges examined. ${ }^{158}$ Given this expense, those towns and cities that could expect an entry soon after a king's coronation preferred not to seek the confirmation of their rights at court unless it was absolutely necessary. ${ }^{159}$

Yet for towns located far from the centre of royal power, the opportunity to have their privileges validated at the start of a reign reduced the period of uncertainty that inevitably followed a monarch's death. When a delegation from Toulouse appeared before Henry II at Saint-Germain-en-Laye on 30 May 1547 to do homage to the new king, Anne de Montmorency, the constable and grand-maitre of France, presented its members to the king, who confirmed the city's privileges, franchises and liberties. ${ }^{160}$ Municipal delegations brought copies of their charters to court and asked the king to renew them. There was little negotiation in this act as it was just a general renewal of urban rights. On 13 May 1547 Lyon's town council appointed a delegation to bring copies of their charters to Paris and have Henry II confirm the privileges his predecessors had granted to the city. ${ }^{161}$ Although this was a straightforward renewal of existing urban liberties, urban governments were expected to pay to have their rights confirmed; indeed, Louis XI used the renewal of charters as a means to generate revenue. On 7 October 1461, Jean de Bar, bailli of Touraine, informed Tours' leaders that they would have to pay 1,0oo livres to have their liberties confirmed, while Toulouse paid 1,375 livres to have its privileges renewed in the same year. ${ }^{162}$ Furthermore, municipal councils had to provide gifts to those people who had influence with the king. For Louis XII's entry into Reims in 1498, Châlons-en-Champagne sent a delegation to offer presents of wine to the cardinal of Reims, the chancellor, Georges d'Amboise, and the royal financial

\footnotetext{
$15^{8}$ AM Amiens Bв 25, fols. 39or, 315r.

159 Similarly, the delegation Beavais's municipal council sent to court in 1547 remarked that it had obtained the confirmation of the town's privileges 'with great difficulty': Renaud Rose, Ville de Beauvais. Inventaire sommaire des archives communales antèrieures à 1790 (Beauvais, 1887), 17 .

160 AM Toulouse AA 8/2.

161 Ам Lyon вв 66, fols. 22v, 26r.

162 Ам Tours вв 10, fol. 344r; Aм Toulouse AA 38/8; Bonnafous, 'Toulouse et Louis XI', 122. Despite Tours' initial protests about the poverty of the town and the expense of the gift for Charlotte of Savoy, a civic deputation brought five hundred écus to Louis XI at SaintJean-d'Angely in 1462 when they went to have their privileges confirmed: Rivaud, Villes et le roi, 85 . For payments to have privileges confirmed at the beginning of a monarch's reign see also: Ам Lyon вв 66, fol. 4v; Chevalier, 'King's Council', 113 .
} 
officers (messieurs des finances) 'in order that the said lords recommend the town towards the king our lord after his coronation.' ${ }^{163}$ These men were headhunted by Châlons' échevins because of the influence they had with the king. The archbishop of Reims crowned the monarch, while Georges d'Amboise was one of the Louis XII's closest friends. Furthermore, the chancellor, was responsible for registering the monarch's confirmation of urban liberties. Once Henry II had confirmed Lyon's privileges in 1547, the municipal delegation went immediately to the chancellor to obtain his confirmation of the privileges, after which they were able to have them registered with the procureur of the conseil privé. ${ }^{164}$ Perhaps the most important people targeted by Châlons' échevins in 1498 were the royal financial officers, as they drew up the documents confirming the king's grant. As we shall see in chapter three, it was essential that urban governments had the senior royal secretaries (the sécretaires des finances) ratify the king's grants.

Despite the financial cost, obtaining the confirmation of urban liberties at the beginning of a new monarch's reign had clear advantages for urban administrations. Nonetheless, the gradual removal of this element from the royal entry ceremony changed the character of the extramural greeting: rather than providing a moment of interaction between the king and the city, the extramural greeting increasingly became a channel for the display of royal majesty. Alterations to the form of the extramural greeting contributed to the transformation in the public presentation of the king in the century separating the reigns of Louis XI and Charles IX. Whereas Louis XI was prepared to keel before the mayor of La Rochelle and take an oath to confirm the city's liberties, Charles IX was not. From the late fourteenth century, La Rochelle's municipal council had placed a silk ribbon across the path of the French monarch at his inaugural entry, which was only removed after the king had confirmed the city's privileges. When Charles IX entered La Rochelle in ${ }^{564}$, however, the Crown considered the ribbon to be an affront to the king's majesty and the governor of Guyenne, Guy Chabot, lord of Jarnac, cut through it with his sword. There was no public confirmation of the city's rights and liberties, and in a striking image of royal power the king's cortège tramped over the ribbon as it entered the city. ${ }^{165}$

163 AC Châlons-en-Champagne cc 91, fol. 540r; Paul Pélicier, Ville de Châlons-sur-Marne. Inventaire sommaire des archives communales antérieures à 1790 (Châlons, 1903), 200.

164 Ам Lyon в в 66, fol. 103r.

165 David, Entrées princières, 159-6o. For the wider context of this entry, see: Kevin C. Robbins, City on the Ocean Sea: La Rochelle, 1530-1650 (Leiden, 1997), 194-96. 
While the challenge to monarchical authority unleashed by the civil wars of the later sixteenth century gave a religious resonance to the confirmation of liberties during royal entries into towns and cities containing significant Protestant populations (as at La Rochelle), the underlying issue remained the nature of royal authority. Some urban communities were unable to obtain the king's confirmation of their liberties either at the beginning of his reign or at his inaugural entry. Nîmes was forced to wait for many months after Charles IX's entry into the town to have its liberties confirmed because its Protestant inhabitants had taken up arms against the king during the first religious war. ${ }^{166}$ As Protestants had obtained control of Nîmes' municipal administration by the early 1560 s, the Crown decided to intervene in municipal elections to ensure that Catholic consuls regained dominance of the council in ${ }^{1564} \cdot{ }^{167}$ It is likely that Charles did not confirm the city's liberties because they included the right to form a government. As the Crown wanted to intercede in the formation of Nîmes' government, Charles's entry was planned for December ${ }^{1564}$, around the time of the council elections. Indeed, royal officials orchestrated the appointment of further Catholic consuls during the king's visit. 168 It was not simply the fact that the city was Protestant; it was because these Protestants had risen in opposition to the Crown. In contrast to his actions at Nîmes, Charles IX confirmed the rights of the neighbouring Catholic city of Narbonne during his inaugural entry. ${ }^{169}$ Throughout the religious wars, the king used the public swearing of oaths to bolster the authority of dependable municipal councils in regions where royal power was challenged. In other words, the public confirmation of privileges became a favour the king granted to urban administrations that supported the Crown. Charles removed this element from his entries into towns (Catholic and Protestant) which had challenged his authority. While Henry II confirmed Dijon's liberties at his entry

166 Boutier, Un tour de France royal, 296.

${ }_{167}$ This was part of a kingdom-wide drive by the Crown to reserve the right to allow the king to nominate the candidates in municipal elections. See, for example, the commands Charles IX sent to Angers on 9 August 1564 about this issue, as well those he issued as his entry into Aix-en-Provence: Ам Angers вв 143; Sylvain Bertoldi, Lire les écritures anciennes, 2 vols (Angers, 1991), ii. 65-75; Claire Dolan, 'Rites d'accueil, identité urbaine et représentation politique à Aix-en-Provence au XVI ${ }^{\mathrm{e}}$ siècle', in Massimo Miglio and Giuseppe Lombardi, eds., Simbolo e realtà della vita urbana nel Tardo Medioevo (Manziana, 1993), 300.

168 Allan A. Tulchin, That Men Would Praise the Lord: The Triumph of Protestantism in Nîmes, 1530-1570 (Oxford, 2010), 156-57. For Protestantism at Nîmes see also: A. H. Guggenheim, 'The Calvinist Notables of Nîmes during the Era of the Religious Wars', Sixteenth Century Journal 3 (1972), 89-96.

169 Vaillancourt, Entrées solennelles, Charles $I X, 178-79$. 
in 1548 , this element was removed from Charles IX's entry sixteen years later. ${ }^{170}$ Charles's progress of 1564-66 was designed to impose the terms of the Edict of Amboise (which had brought an end to the first religious war in 1563) across the kingdom. ${ }^{171}$ As the religious freedoms the Edict had granted to Protestants were unpopular with Dijon's staunchly Catholic leaders, both the civic authorities and the Parlement of Burgundy delayed registering it. ${ }^{172}$ Charles considered this to be an affront to royal authority and he used his visit to Dijon to chastise its leaders for their disobedience. As Penny Roberts has found, the implementation of the peace edicts by the Valois monarchy during the religious wars was a crucial means to enforce royal authority. ${ }^{173}$ Regardless of a town's religious composition, the key issue for the king was that municipal elites gave him their unswerving loyalty, in return for which he granted them liberties that sustained their place at the head of urban society. Moreover, as Charles IX made clear to recalcitrant townspeople at his entries, these liberties could be taken away if they defied him.

\section{The Loggia}

An increasing stress on the majesty of the Valois monarchy was manifested in the physical presence of an entry in the mid-sixteenth century, most notably with the emergence of the loggia (a raised wooden platform, often in the form of a gallery, which was decorated with tapestries and other expensive ornaments). ${ }^{174}$ These structures - which were erected outside the gate of entry in the lead up to a royal visit - fundamentally altered the interaction between

170 Gouvenain, Inventaire sommaire, Dijon, i. 67, 78; ii. 9-11.

171 Penny Roberts, Peace and Authority during the French Religious Wars, c.1560-160o (Basingstoke, 2013), 68-69.

172 Robert J. Knecht, Hero or Tyrant? Henry III, King of France, 1574-89 (Farnham, 2014), 17-18. As the Parlement of Bordeaux delayed registering the Edict of Amboise, Charles IX enforced it following his entry into the city: H. de Montégut, ed., Journal historique de Pierre de Jarrige, viguier de la ville de Saint-Yrieix (1560-1574) (Angoulême, 1868), 16.

173 Penny Roberts, 'Royal Authority and Justice during the French Religious Wars', Past \& Present 184 (2004), 3-32; idem, 'Religious Pluralism in Practice: The Enforcement of the Edicts of Pacification', in K. Cameron, M. Greengrass and P. Roberts, eds., The Adventures of Religious Pluralism in Early Modern France (Bern, 2000), 31-43.

174 M. Boudon, M. Chatenent and A.-M. Lecoq, 'La mis en scène de la personne royale en France au XVI ${ }^{\mathrm{e}}$ siècle: premières conclusions', in Jean-Philippe Genet, ed., L'État moderne: genèse. Bilans et perspectives (Paris, 1990), 241, 245; Wagner, Entrées royales, Henri IV, 39-40. 
the king and the municipal elite. Rather than meeting the urban delegation on horseback, the monarch arrived outside the town in advance of the entry and waited for the townspeople while seated on the raised platform of the loggia. For Henry II's entry into Paris in 1549, the échevins built a wooden stand at the end of the rue Saint-Laurent from where the king could sit and watch the extramural procession of townspeople. ${ }^{175}$ Before Henry II's reign, municipal delegations brought a halt to the movement of the royal cortège and only moved aside to allow the king to continue his journey into the town after he had taken an oath to safeguard urban rights; in contrast, by the mid-sixteenth century, the king remained stationary and the townspeople came to greet him.

Loggias were first used in cities across the kingdom (including Lyon, Nantes, Paris and Rouen) for the entries of the French king during the reign of Henry II. While contemporary sources do not reveal where the initiative for this development came from, the French monarchy was exerting more control over the form of the ceremonial entry in the 1540 s. $^{176}$ There were precedents for the use of similar structures in ecclesiastical and ducal entries into northern French towns which the Crown could draw on. When he entered Rouen in 1532, Antoine Duprat, archbishop of Sens, papal legate and chancellor of France, received three formal greetings (from the bailli, the town council and the Parlement of Rouen) while seated 'in his chair' outside the city walls. ${ }^{177}$ In the same year the king's eldest son, Francis, sat on a 'great stage' outside Rennes to watch processions of townspeople come to greet him during the

175 Guérin, Registres Paris, 1539-1552, 164, 180.

176 Lawrence M. Bryant, 'From Ephemeral to Perdurable Rituals and Ceremonies', in idem, Ritual, Ceremony and the Changing Monarchy, 4.

177 AD Seine-Maritime, AM Rouen A 13, fol. 18r. While many bishops were carried in a chair by their vassals during their inaugural entries, this was not the custom at Rouen: Véronique Julerot, 'La première entrée de l'évêque: réflexions sur son origine', Revue historique 639 (2006), 641-42. For this custom at bishops' entries, see: Henry Jongleux, ed., Archives de la ville de Bourges avant 1789, 2 vols (Bourges, 1877), i. 222; Rivaud, Entrées princières, 62, 96; Pierre Debofle, 'Le cérémonial des archevêques au temps de la Renaissance: l'exemple de l'entrée du cardinal de Clermont-Lodève dans la ville d'Auch en 1512', Bulletin de la Société archéologique, historique, littéraire et scientifique du Gers (2002), 422; Charles Lalore, 'Documents sur l'abbaye de Notre-Dame-aux-Nonnains de Troyes', Mémoires de la Société d'agriculture, sciences et arts du département de l'Aube 11 (1874), 173; Marquis de Sécillon, 'Les premières entrées des évêques de Nantes en la ville de Guérande', Bulletin de la Société archéologique de Nantes et du département de la Loire-Inférieure 23 (1884), 192; Julien Théry, 'Les entrées épiscopales à Thérouanne (X $\mathrm{X}^{\mathrm{e}} \mathrm{XVI} \mathrm{I}^{\mathrm{e}}$ siècles)', in L'album Thérouanne (forthcoming), p. 6; Bertrand Yeuch, 'Les premières entrées épiscopales en Bretagne ducale', Britannia Monastica 16 (2012), 121-22. 
ducal coronation entry. ${ }^{178}$ As some of the very earliest uses of the loggia in France were for members of the Habsburg family, this new device may also represent the introduction of a foreign custom into French entries. By the terms of the Habsburg-Valois peace of 1529, Francis I married Charles v's sister, Eleanor of Austria. For her post-coronation entry into Paris in 1531, the Parisians erected a stage for the queen outside the Saint Ladre gate, where she sat and watched processions of townspeople come out of the city to honour her. ${ }^{179} \mathrm{~A}$ loggia was also used at Paris for the entry of Emperor Charles V in January 1540. The municipal council constructed a 'wooden house surrounded with glass' next to the church of Saint-Antoine-des-Champs, where the emperor sat next to the French king's sons and with the chancellor and constable of France on either side of him. ${ }^{180}$ There are good reasons to believe that this entry influenced the incorporation of the loggia into French royal entries in the mid-sixteenth century, as the future Henry II was one of those people who sat beside Charles $v$ to watch the Parisians greet the emperor. Upon coming to the throne in 1547 , Henry II renewed the war against Charles v. As part of its propaganda efforts, the Crown used display as a way to assert the Valois monarch's superiority over his Habsburg rival. Furthermore, Henry appears to have imitated the manner in which Charles V interacted with the Parisian delegation at his entry into the city in 1540 . When Charles $\mathrm{v}$ received a greeting from the prévôt des marchands, he did not reply in person; rather, he had the constable thank the city on his behalf. ${ }^{181}$ Henry II adopted this manner - which was uncustomary for French kings - when he made his entry into the city nine years later (see below). ${ }^{182}$

No matter where the initiative to use the loggia came from (whether royal or civic), it was probably the growing popularity of festival books during the sixteenth century that led to its increasing adoption by cities across France. The development of festival books enabled the rapid diffusion of trends across

178 Godefroy, Cérémonial françois, i. 611. For this entry, see: AM Rennes MS. 126.C.6, fol. 176r; Paul de La Bigne Villeneuve, 'Extrait d'une relation manuscrite sur l'entrée et couronnement du duc François III de ce nom en la ville de Rennes, capital du duché de Bretagne', Bulletin et mémoires de la Société archéologique du départment d'Ille-et-Vilaine 14 (1880), 307-20.

179 Tuetey, Registres Paris, 1527-1539, 111. Although Francis I and Eleanor of Austria did not enter Amiens in 1536, the town council constructed a wooden stage for the queen outside the city's Paris gate, from where she could watch the six thousand soldiers of the Picard legions parade past her: Ам Amiens в В 23, fol. $7 \mathrm{v}$.

180 Guérin, Registres Paris, 1539-1552, 9.

181 Guérin, Registres Paris, 1539-1552, 9.

182 Guérin, Registres Paris, 1539-1552, 64. 
the kingdom, as cities competed to outdo each other in the magnificence of their entries. Lyon appears to have been the first city to construct a loggia for a French king's entry (that of Henry II in 1548). ${ }^{183}$ It is significant that the festival book for this entry was published quickly and distributed widely. ${ }^{184}$ Lyon was a centre of innovation for royal entries in sixteenth-century France; indeed, it was the first city to use triumphal arches in its receptions (Francis I in 1515), which was a feature soon copied by other towns and cities across the kingdom. ${ }^{185}$ French municipal councils looked to Lyon for inspiration when planning their entries. A loggia was first used at Rouen for Henry II's entry in 1550, which the échevins designed in response to knowledge of practices at Lyon. ${ }^{186}$ Once adopted, loggias became a regular feature of French royal entries, with their use spreading across the kingdom during the reigns of Charles IX and Henry III. ${ }^{187}$ The mid-ranking town of Angers constructed a loggia for the entry of Charles IX in $1565 .{ }^{188}$ By the 1570 , Angers was constructing loggias (in imitation of their use for the king) for the entries of other members of

183 AC Lyon вв 67, fol. 282r; cC 980, no. 2.

184 Georges Guigue, ed., La magnificence de la superbe et triumphante entrée de la noble \& antique Cité de Lyon faicte au Treschrestien Roy de France Henry deuxiesme de ce Nom, Et à la Royne Catherine son Espouse le XXIII de Septembre M.D.XLVIII (Lyon, 1927), 4.

185 Georges Guigue, ed., L'entrée de François premier roy de France en a cité de Lyon le 12 juillet 1515 (Lyon, 1899), ix-x; Neil Murphy, 'Building a New Jerusalem in Renaissance France: Ceremonial Entries and the Transformation of the Urban Fabric, 1460-16oo', in Katrina Gullier and Helena Tóth, eds., Cityscapes in History: Creating the Urban Experience (Farnham, 2014), 186-88. Lyon had planned to erect a triumphal arch for the entry of Louis XII in 1509, though the king did not visit the city: Cooper, Roman Antiquities, 143; Hochner, Louis XII, 113. For triumphal arches see: Zdzislaw Bieniecki, 'Quelques remarques sur la composition architecturale des arcs de triomphe à la renaissance', in Jean Jacquot and Elie Konigson, eds., Les fêtes de la Renaissance, tome 3: Quinzième colloque international d'études humanistes, Tours, 10-22 juillet, 1972 (Paris, 1975), 200-15.

186 AD Seine-Maritime, Am Rouen A 16, fol. 13v.

187 Boutier, Tour de France royal, 294-95; Vaillancourt, Entrées solennelles, Charles IX, 113; Rivaud, Entrées princières, 159; David Rivaud, 'L'accueil des souverains par les corps de villes: les entrées royales dans les "bonnes villes" du Centre-Ouest (XVe-XVIe siècles)', Mémoires de la Société des antiquaires de l'Ouest 8 (2002), 277.

188 Ам Angers вв 30, fol. 226r. Several other towns and cities (including Bordeaux and Tours) also constructed loggias for the first time in 1565: David Rivaud, 'Les entrées solennelles de la Renaissance à Tours (1461-1565)', Bulletin de la Société archéologique de Touraine 57 (2011), 157. Limoges used a loggia for the first time for the entry of the Antoine de Bourbon, vicomte of Limoges and king of Navarre in December 1556: Ruben, Registres consulaires, Limoges, ii. 110-11. 
the royal family. ${ }^{189}$ These structures were principally confined to the larger towns and cities of the kingdom, as the cost of their fabrication exceeded the financial capabilities of the kingdom's smaller urban communities. As loggias were expensive to construct, they acted as both a mark of urban prosperity and as a means to honour the king (and thus encourage him to respond with generous gifts).

Although the incorporation of the loggia into the entry ceremony allowed urban governments to greet the monarch in an especially magnificent way, it also created a distance between him and the municipal delegation. The character of the extramural greeting changed from being a moment of exchange to become an occasion when townspeople honoured the majesty of the French king, who was aloof and resplendent on a dais. When Henry II entered Nantes, he sat in the loggia where he could 'see, receive and hear the very affectionate zeal and willingness that the Nantais had shown for his blessed coming'.190 There is little sense of the reciprocal obligations that typified the extramural greeting before the mid-sixteenth century. In some towns and cities, the inclusion of the loggia profoundly altered the nature of the extramural greeting. Before 1531, Paris's municipal council customarily met visiting French kings and queens in an enclosed space in La-Chapelle-Saint-Denis. The greeting was hidden from public view and it normally only involved the participation the town council, the royal family and their officials. However, the incorporation of the loggia meant that the greeting was moved outside into open air and thus into the wider public gaze. Yet, while this aspect of the Parisian entry focused on the public presentation of the majesty of the French monarchy, it also acted as a means for the city council to highlight its close links to the royal family in front of a large and socially diverse audience. ${ }^{191}$ As the size of the extramural procession of townspeople grew substantially from the mid-sixteenth century, this move allowed Paris's leaders to underscore their elite status to more townspeople than ever before. It dovetailed with the efforts Paris's civic administration took in the sixteenth century to use a ceremonial entry specifically to display their status to the general population. For example, while the civic council normally assembled outside the walls in preparation for the

189 See, for example, the entry of Francis, duke of Anjou, and brother to Henry III, in 1578: Ам Angers в в 35, fol. 333r; Sylvain Bertoldi, 'Les entrées des rois et des enfants de France à Angers de 1424 à 1598', Bulletin de la Société nationale des antiquaires de France (1994), $325^{-28}$.

190 M. Rathouis, 'Entrée du roi Henri II à Nantes le 12 juillet 1551', Bulletin de la Société archéologique de Nantes et de Loire-Atlantique 1 (1859), 49.

191 On this point, see: Bryant, King and the City, 97. 
extramural greeting during the fifteenth century, from the 1530 s they met at the town hall and marched in a procession through the streets before exiting the city, thus displaying their power to the wider population. It is striking to note that this measure was first used at Paris for the entry of Eleanor of Austria in 1531, which - as we saw - was also the first time a loggia was erected for an entry into the city. ${ }^{192}$ As such, there is the possibility that the Parisians introduced a loggia into entries as part of their wider strategy to use an entry to parade their elite status to the general population.

Prior to the mid-sixteenth century, urban elites had unfettered access to the king during the extramural greeting. They did not have to pass through intermediaries, nor were there barriers around the king. However, the introduction of the loggia fundamentally altered this process. Royal officials, such as the chancellor, now regulated access to the king by introducing the urban delegation into the king's presence. Prior to mid-sixteenth century, Mâcon's municipal council approached the monarch directly during the extramural greeting. However, when Charles IX entered Mâcon in 1564, the governor first presented the town council to the duke of Aumale and then to the king. ${ }^{193}$ The loggia's design was adapted over time to help control access to the monarch. In 1571, Charles IX sat on a scaffold outside Paris to receive the harangues. A dais covered with Turkish carpets was placed on the scaffold and - as a means to avoid disorder among those going up to greet the king - two large staircases were incorporated into the design to control access to the monarch. ${ }^{194}$ As a consequence of these architectural changes, royal officials could restrict the amount of direct contact the king had with urban officials during the ceremony.

In sum, the development of a heightened reserve and lack of public dialogue between the king and his urban subjects formed an important element in the Crown's drive to accentuate the majesty of the French monarchy in the mid-sixteenth century. Whereas Louis XI conversed freely with his urban subjects, Henry II maintained a public distance from even the urban elite. While Francis I replied in person to municipal greeting speeches (and even displayed considerable emotion when doing so), his son Henry II often remained motionless, like a statue, during the extramural greeting. When Claude Guyot,

192 Before going out to greet Eleanor of Austria in 1531, the Parisian civic delegation departed from the town hall went down the rue de la Vannerie as far as the Paris gate, where it turned into the rue Saint-Denis and went up to the Saint-Denis gate: Tuetey, Registres Paris, 1527-1539, 113 .

193 Aм Mâcon B B 39, fols. 79r-79v.

194 Graham and Johnson, Paris Entries, 165-66. See also: Reuben, Registres consulaires, Limoges, ii. 111 . 
the prévôt-des-marchands of Paris, delivered his harangue to Henry in 1549, the monarch sat silent on a dais and had the chancellor reply on his behalf. ${ }^{195}$ From the mid-sixteenth century, the French king restricted the extent of his interaction in the extramural greeting, becoming a spectator who sat immobile and watched the procession of townspeople file past him. Yet, the confirmation of liberties remained a part of some entries well beyond the reign of Henry II, in addition to which the municipal elite's close and privileged contact with the king allowed them to maintain their authority over the general urban population.

The royal entry ceremony was the principal occasion for the confirmation of urban liberties by the fourteenth century. Oaths lay at the heart of the operation of western European states during this period and the king's confirmation of urban privileges was the most important aspect of the ceremony for townspeople. ${ }^{196}$ Urban elites embedded the confirmation of municipal liberties within the extramural greeting as a means to emphasise the contractual nature of monarchical rule. Yet, as towns opted to have their liberties confirmed at the beginning of a new monarch's reign, there was a gradual decline in this function of the extramural greeting. Nonetheless, we should not overstate the speed of this transformation. While the move to have urban rights confirmed at court is apparent from the resurgence of Valois power in the 1430 , it did not become widespread until the middle of the sixteenth century. In many respects, it was preferable for urban populations to have their liberties confirmed in this way, as there could be a long gap between the ascension of a ruler and his first entry, especially in more remote parts of the kingdom.

Although the initiative to have municipal liberties confirmed at court came from the towns, it brought clear advantages to the Crown. In particular, it transformed the presentation of monarchical power during a royal entry. Prior to the appearance of the loggia, it was customary for the king to greet the town council on horseback and exchange greetings with the speaker. This form of greeting emphasised the scope of civic jurisdiction, as the municipal

195 Guérin, Registres Paris, 1539-1552, 64.

196 Corinne Leveleux-Teixeira, 'Des serments collectifs au contrat politique? (début du $\mathrm{XV}^{\mathrm{e}}$ siècle)', in François Foronda, ed., Avant le contrat social. Le contrat politique dans l'Occident médiéval XIII ${ }^{e}-X V^{e}$ siècle (Paris, 2011), 269; Neil Murphy, 'Ceremonial Entries and the Confirmation of Urban Privileges in France, c.1350-1550', in Jeroen Duindam and Sabine Dabringhaus, eds., The Dynastic Centre and the Provinces: Agents and Interactions (Leiden, 2014), 161-62; Michélè Populer, 'Les entrées inaugurales des princes dans les villes. Usage et signification. L'exemple des trois comtes de Hainaut, Hollande et Zelande entre 1417 et 1433', Revue du Nord 76 (1994), 29-30. 
delegation stood blocking the road until the king swore an oath to uphold their liberties. While the confirmation or re-confirmation of urban liberties was not completely eradicated from royal entries by the reign of Charles IX, it took place less frequently. ${ }^{197}$ Despite these transformations to the form of the extramural greeting, a royal entry remained an important event for townspeople because it provided urban governments with access to the king, which they used to present him with petitions for new liberties.

197 We can also see a similar process at work in the French king's territories in Italy during the mid-sixteenth century. While Henry II made a progress around Piedmont in 1548, and entered towns and cities such as Turin, he did not confirm their liberties until he had returned to France: Michel Antoine, 'Institutions françaises en Italie sous le règne de Henri II: gouverneurs et intendents', Mélanges de l'École française de Rome 94 (1982), 768. 